National Water Census

\title{
Estimation of Daily Mean Streamflow for Ungaged Stream Locations in the Delaware River Basin, Water Years 1960-2010
}
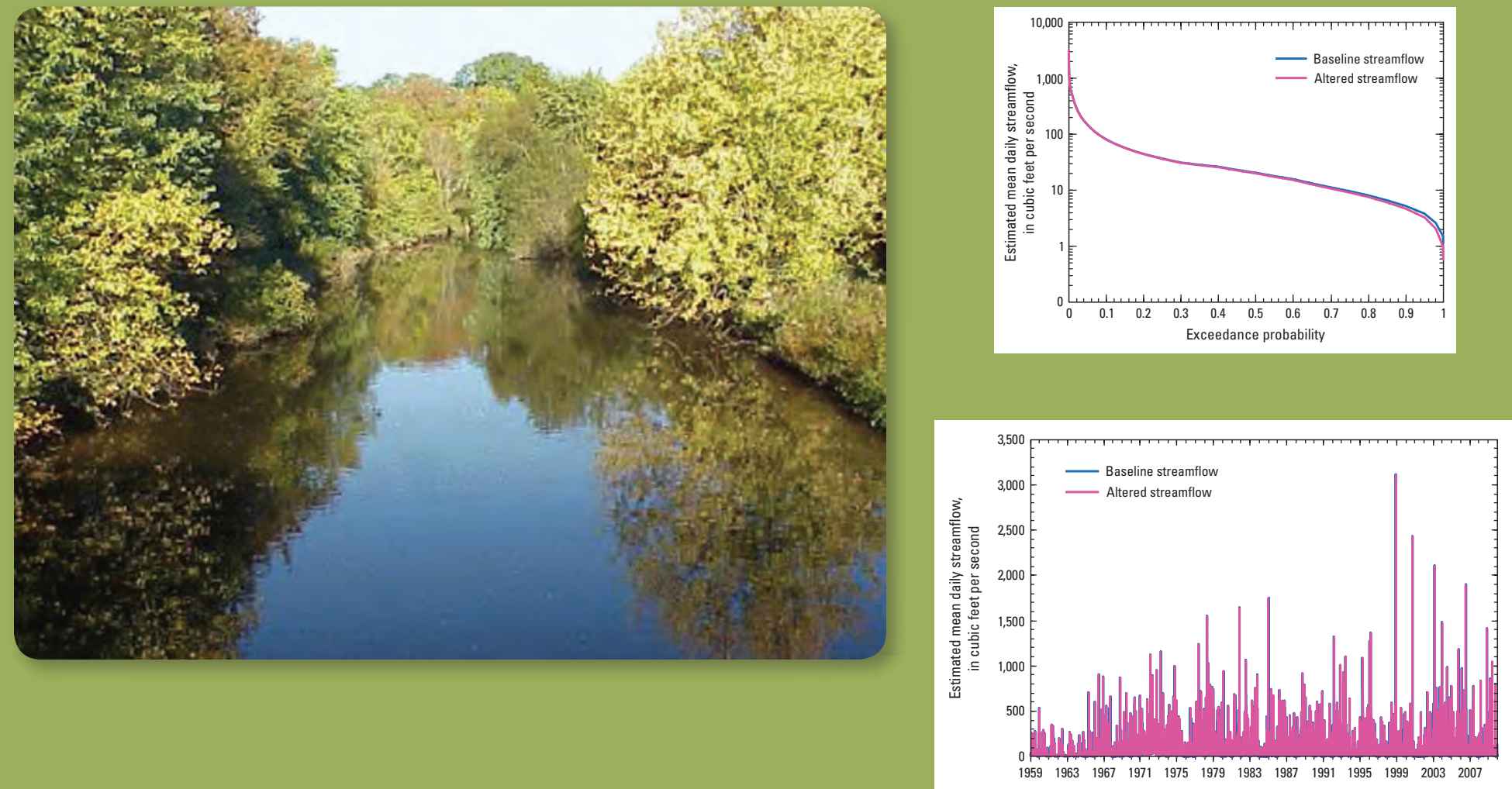

Scientific Investigations Report 2015-5157

U.S. Department of the Interior U.S. Geological Survey 
Cover. Little Neshaminy Creek near Neshaminy, Pennsylvania, looking upstream. Photograph courtesy of U.S. Geological Survey Pennsylvania Water Science Center Hydrologic Surveillance Program staff, Exton office.

(Top graph) Flow-duration curve, in cubic feet per second, for ungaged site under baseline and altered flow conditions. (Bottom graph) Baseline and altered hydrograph, in cubic feet per second, for ungaged site. 


\section{Estimation of Daily Mean Streamflow for Ungaged Stream Locations in the Delaware River Basin, Water Years 1960-2010}

By Marla H. Stuckey

National Water Census

Scientific Investigations Report 2015-5157 


\title{
U.S. Department of the Interior SALLY JEWELL, Secretary
}

\section{U.S. Geological Survey Suzette M. Kimball, Director}

\author{
U.S. Geological Survey, Reston, Virginia: 2016
}

For more information on the USGS - the Federal source for science about the Earth, its natural and living resources, natural hazards, and the environment, visit http://www.usgs.gov or call 1-888-ASK-USGS

For an overview of USGS information products, including maps, imagery, and publications, visit http://store.usgs.gov

To order this and other USGS information products, visit http://store.usgs.gov

Any use of trade, product, or firm names is for descriptive purposes only and does not imply endorsement by the U.S. Government.

Although this report is in the public domain, permission must be secured from the individual copyright owners to reproduce any copyrighted materials contained within this report.

Suggested citation:

Stuckey, M.H., 2016, Estimation of daily mean streamflow for ungaged stream locations in the Delaware River Basin, water years 1960-2010: U.S. Geological Survey Scientific Investigations Report 2015-5157, 42 p., http://dx.doi.org/10.3133/sir20155157.

ISSN 2328-0328 (online) 


\section{Contents}

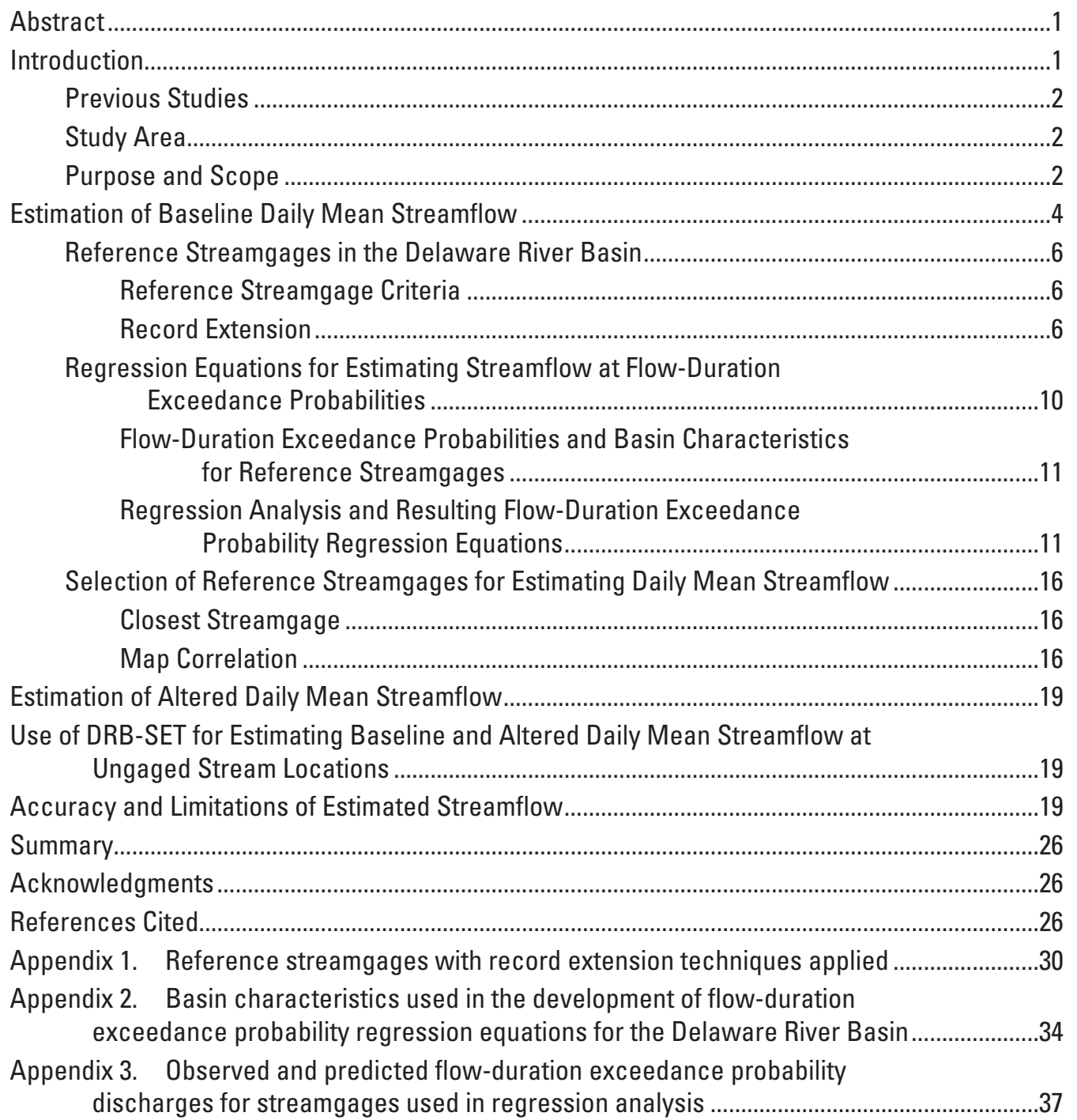




\section{Figures}

1. Map showing physiographic provinces of the Delaware River Basin.

2. Graphical representation of the QPPO methodology, showing

$A$, observed daily mean streamflow at a reference streamgage,

$B$, flow-duration curve at the reference streamgage, $C$, constructed flow-duration curve at the ungaged stream location, and $D$, estimated daily mean streamflow at the ungaged stream location.

3. Map showing location of U.S. Geological Survey reference streamgages in or near the Delaware River Basin

4. Histogram showing percent impervious area in the reference streamgage subbasins within the Delaware River Basin

5. Histogram showing the number of reference streamgages requiring record extension and the number of years of record extension,

Delaware River Basin

6. Example streamflow correlation map for U.S. Geological Survey streamgage 01559000, Juniata River at Huntingdon, $\mathrm{Pa}$.

7. Box plot and map showing the distribution of root mean square error between the observed and estimated streamflow correlations, resulting from map correlation, for 109 streamgages in and near the Delaware River Basin

8. Screen capture of an example report generated by the Delaware River Basin Streamflow Estimator Tool showing water use, a flow-duration curve, and a hydrograph

9. Graph showing Nash-Sutcliffe efficiency values determined using the closest streamgage and map correlation in the Delaware River Basin Streamflow Estimator Tool

10. Graph showing distribution of Nash-Sutcliffe efficiency values between observed and estimated daily mean streamflows in the Upper and Lower Delaware River Basin

11. Map showing spatial distribution of Nash-Sutcliffe efficiency values for reference streamgage basins in the Delaware River Basin

12. Hydrographs and flow-duration curves showing estimated and observed daily mean streamflows for U.S. Geological Survey streamgages $A, 01420500$, Beaver Kill at Cooks Falls, New York, water years 1999-2002, and B, 01464500, Crosswicks Creek at Extonville, New Jersey, water years 1999-2002

\section{Tables}

1. U.S. Geological Survey reference streamgages in and near the Delaware River Basin

2. Basin characteristics used in the development of regression equations for flow-duration exceedance probabilities for streams in the Delaware River Basin.

3. Regression coefficients for use with flow-duration exceedance probability regression equations for streams in the Delaware River Basin.....

4. Range of basin characteristics used in the development of regression equations to estimate flow-duration exceedance probability discharges for ungaged stream locations within the Delaware River Basin

5. Nash-Sutcliffe efficiency values between observed and estimated daily mean streamflows in the Delaware River Basin 


\section{Conversion Factors and Datums}

\begin{tabular}{|c|c|c|}
\hline Multiply & By & To obtain \\
\hline \multicolumn{3}{|c|}{ Length } \\
\hline inch (in.) & 2.54 & centimeter $(\mathrm{cm})$ \\
\hline foot $(\mathrm{ft})$ & 0.3048 & $\operatorname{meter}(\mathrm{m})$ \\
\hline mile (mi) & 1.609 & kilometer $(\mathrm{km})$ \\
\hline \multicolumn{3}{|c|}{ Area } \\
\hline acre & 4,047 & square meter $\left(\mathrm{m}^{2}\right)$ \\
\hline square mile $\left(\mathrm{mi}^{2}\right)$ & 259.0 & hectare (ha) \\
\hline square mile $\left(\mathrm{mi}^{2}\right)$ & 2.590 & square kilometer $\left(\mathrm{km}^{2}\right)$ \\
\hline \multicolumn{3}{|c|}{ Flow rate } \\
\hline cubic foot per second $\left(\mathrm{ft}^{3} / \mathrm{s}\right)$ & 0.02832 & cubic meter per second $\left(\mathrm{m}^{3} / \mathrm{s}\right)$ \\
\hline $\begin{array}{l}\text { cubic foot per second per square } \\
\text { mile }\left[\left(\mathrm{ft}^{3} / \mathrm{s}\right) / \mathrm{mi}^{2}\right]\end{array}$ & 0.01093 & $\begin{array}{l}\text { cubic meter per second per square } \\
\text { kilometer }\left[\left(\mathrm{m}^{3} / \mathrm{s}\right) / \mathrm{km}^{2}\right]\end{array}$ \\
\hline cubic foot per day $\left(\mathrm{ft}^{3} / \mathrm{d}\right)$ & 0.02832 & cubic meter per second $\left(\mathrm{m}^{3} / \mathrm{s}\right)$ \\
\hline gallon per day $(\mathrm{gal} / \mathrm{d})$ & 0.003785 & cubic meter per day $\left(\mathrm{m}^{3} / \mathrm{d}\right)$ \\
\hline $\begin{array}{l}\text { gallon per day per square mile } \\
{\left[(\mathrm{gal} / \mathrm{d}) / \mathrm{mi}^{2}\right]}\end{array}$ & 1,233 & cubic meter $\left(\mathrm{m}^{3}\right)$ \\
\hline million gallons per day $(\mathrm{Mgal} / \mathrm{d})$ & 0.001233 & cubic hectometers $\left(\mathrm{hm}^{3}\right)$ \\
\hline inch per hour (in/h) & 0.0254 & meter per hour $(\mathrm{m} / \mathrm{h})$ \\
\hline inch per year (in/yr) & 25.4 & millimeter per year $(\mathrm{mm} / \mathrm{yr})$ \\
\hline \multicolumn{3}{|c|}{ Hydraulic conductivity } \\
\hline foot per day (ft/d) & 0.3048 & meter per day $(\mathrm{m} / \mathrm{d})$ \\
\hline
\end{tabular}

Temperature in degrees Fahrenheit $\left({ }^{\circ} \mathrm{F}\right)$ may be converted to degrees Celsius $\left({ }^{\circ} \mathrm{C}\right)$ as follows:

$$
{ }^{\circ} \mathrm{C}=\left({ }^{\circ} \mathrm{F}-32\right) / 1.8
$$

Vertical coordinate information is referenced to the North American Vertical Datum of 1988 (NAVD 88).

Horizontal coordinate information is referenced to the North American Datum of 1983 (NAD 83). 



\title{
Estimation of Daily Mean Streamflow for Ungaged Stream Locations in the Delaware River Basin, Water Years 1960-2010
}

\author{
By Marla H. Stuckey
}

\section{Abstract}

The ability to characterize baseline streamflow conditions, compare them with current conditions, and assess effects of human activities on streamflow is fundamental to water-management programs addressing water allocation, human-health issues, recreation needs, and establishment of ecological flow criteria. The U.S. Geological Survey, through the National Water Census, has developed the Delaware River Basin Streamflow Estimator Tool (DRB-SET) to estimate baseline (minimally altered) and altered (affected by regulation, diversion, mining, or other anthropogenic activities) and altered streamflow at a daily time step for ungaged stream locations in the Delaware River Basin for water years 19602010. Daily mean baseline streamflow is estimated by using the QPPQ method to equate streamflow expressed as a percentile from the flow-duration curve (FDC) for a particular day at an ungaged stream location with the percentile from a FDC for the same day at a hydrologically similar gaged location where streamflow is measured. Parameter-based regression equations were developed for 22 exceedance probabilities from the FDC for ungaged stream locations in the Delaware River Basin. Water use data from 2010 is used to adjust the baseline daily mean streamflow generated from the QPPQ method at ungaged stream locations in the Delaware River Basin to reflect current, or altered, conditions. To evaluate the effectiveness of the overall QPPQ method contained within DRB-SET, a comparison of observed and estimated daily mean streamflows was performed for 109 reference streamgages in and near the Delaware River Basin. The Nash-Sutcliffe efficiency (NSE) values were computed as a measure of goodness of fit. The NSE values (using $\log _{10}$ streamflow values) ranged from 0.22 to 0.98 (median of 0.90 ) for 45 streamgages in the Upper Delaware River Basin and from -0.37 to 0.98 (median of 0.79 ) for 41 streamgages in the Lower Delaware River Basin.

\section{Introduction}

The National Water Census is a U.S. Geological Survey (USGS) research program, funded through WaterSMART, for national water availability and use that develops new water accounting tools and assesses water availability at regional and national scales. WaterSMART, which stands for Water Sustain and Manage America's Resources for Tomorrow, is an initiative launched by the U.S. Department of the Interior in February 2010. Through the National Water Census, the USGS is integrating diverse research on water availability and use and enhancing the understanding of the connection between water quality and water availability (Alley and others, 2013). The research is designed to build the decision support capacity for water-management agencies and other naturalresource managers. The National Water Census identified three geographic Focus Areas that would benefit from cutting edge approaches to assessing water availability while also serving as pilot studies where multiple lines of research could be integrated and designed to meet stakeholders' information needs. Each Focus Area offers unique challenges that the USGS could investigate at the scale of a large river basin. The Delaware River Basin was selected as one of these Focus Areas.

The Delaware River Basin covers more than 13,500 square miles $\left(\mathrm{mi}^{2}\right)$ in parts of four states, including New York, New Jersey, Pennsylvania, and Delaware. The population in the basin is approximately 8.3 million people. The basin has the largest inter-basin withdrawals of water east of the Mississippi River and provides drinking water to more than 15 million people (Delaware River Basin Commission, 2013). After a history of litigation, many of the water-management decisions regarding the Delaware River system are now coordinated through an interstate river basin commission known as the Delaware River Basin Commission (DRBC). In the upper parts of the basin, concerns over the effects of proposed unconventional shale gas development and the freshwater 
requirements for a recently discovered endangered mussel species (Lellis, 2001) have added new complexities to water management. One of the needs identified by stakeholders in the basin was the need for a scientific approach to define relations between streamflow processes and the responses of aquatic organisms in tributary streams.

Hydrologic and ecological data can be directly related to provide the basis for understanding the flow needs of aquatic species found in the tributaries in the Delaware River Basin. Because the aquatic species living in tributaries are often susceptible to minor changes in streamflow, proactive management measures incorporating the principles of ecological flow science can be implemented to promote the long-term ecological sustainability of these waters. Providing the data and tools to understand and define flow-alteration ecological-response relations will assist water-resource managers and policy makers in making water use decisions that meet the ecological flow needs of aquatic species in the Delaware River Basin.

Maintenance of the natural flow regime of a stream or river is vital to the sustainability and health of aquatic freshwater ecosystems. The ability to characterize baseline, or minimally altered, streamflow conditions, compare them with current conditions, and assess the effects of human activities on streamflow is fundamental to water-management programs addressing water allocation, human-health issues, recreation needs, and the establishment of ecological flow criteria. Waterresource managers undertaking an in-depth evaluation of flow regimes to promote instream ecological health often require daily mean streamflow information to determine streamflow statistics that fulfill their individual needs. Typically, this information is obtainable only from a time series hydrograph. The USGS, through the National Water Census, has developed a tool to estimate streamflow at a daily time step for ungaged stream locations in the Delaware River Basin. The hydrologic information provided by this tool can be used to provide a foundation for ecological flow science in the basin.

\section{Previous Studies}

Fennessey (1994) introduced a method, termed the "QPPQ method," to estimate streamflow statistics for an ungaged stream location. This method was used by Hughes and Smakhtin (1996), Smakhtin (1999), Smakhtin and Masse (2000), Mohamoud (2008), Archfield and others (2010), Shu and Ourda (2012), Stuckey and others (2014), and Gazoorian (2015). Archfield and Vogel (2010) developed a method for selecting an appropriate streamgage for an ungaged stream location on the basis of streamflow correlation (termed the "map correlation method"). These two methods have been successfully applied in Massachusetts (Archfield and others, 2010), the Connecticut River Basin (Archfield and others, 2012), Pennsylvania (Stuckey and others, 2014), and New York (Gazoorian, 2015) to generate daily mean streamflows for ungaged stream locations. Regression equations for estimating streamflow at 17 flow-duration exceedance probabilities from the flow-duration curve were developed for Pennsylvania in conjunction with the Baseline Streamflow Estimator Tool (Stuckey and others, 2014). Water use, including reported and estimated withdrawals and returns, for the Delaware River Basin is documented in Hutson and others, in press.

\section{Study Area}

The Delaware River Basin encompasses 13,539 $\mathrm{mi}^{2}$, draining parts of Pennsylvania $\left(6,422 \mathrm{mi}^{2}\right.$, or 50.3 percent of the basin's total land area), New Jersey $\left(2,969 \mathrm{mi}^{2}\right.$, or 23.3 percent), New York (2,362 $\mathrm{mi}^{2}$, or 18.5 percent), and Delaware (1,004 $\mathrm{mi}^{2}$, or 7.9 percent). Some subbasins within the Delaware River Basin drain directly into Delaware Bay $\left(782 \mathrm{mi}^{2}\right)$. A total of 216 tributary streams enter the Delaware River, making a total of approximately 23,700 linear stream miles in the river system (http://www.state.nj.us/drbc/basin/). The largest tributaries are the Schuylkill River and the Lehigh River in Pennsylvania, which together drain 3,281 $\mathrm{mi}^{2}$.

Five major physiographic provinces compose the Delaware River Basin (fig. 1) (Fischer and others, 2004). The northern third of the basin is covered by the Appalachian Plateaus Physiographic Province, which is composed of gently folded sandstones, shales, and conglomerates. The Valley and Ridge Physiographic Province is adjacent and south of the Appalachian Plateau Physiographic Province and consists primarily of sandstones and shales that form ridges and valleys. Glaciation during the Pleistocene Epoch covered the upper half of the basin, extending to the New England Physiographic Province, which is an upland ridge of metamorphosed shales and carbonate rocks. The Piedmont Physiographic Province is the most highly socioeconomically developed province in the basin and is separated geographically into two sectionsthe Uplands Section which is composed of metamorphic and igneous rocks, and the Lowlands Section, which is primarily composed of clastic rocks. The most southern physiographic province is the Coastal Plain, which is composed of unconsolidated sediment.

The climate in the Delaware River Basin varies depending on the topography and latitude. Average annual temperature ranges from about 45 degrees Fahrenheit $\left({ }^{\circ} \mathrm{F}\right)$ in the northern part of the basin to $56^{\circ} \mathrm{F}$ in the southern part. Average annual precipitation ranges from about 50 inches (in.) in the north to 42 in. in the south (Jenner and Lins, 1991).

\section{Purpose and Scope}

This report presents the data and methodology used to estimate daily mean streamflow for water years ${ }^{1} 1960-2010$ for ungaged locations on streams in the Delaware River Basin.

\footnotetext{
${ }^{1}$ Water year (WY) is defined as a 12-month period beginning October 1 and ending September 30. The water year is designated by the calendar year in which it ends.
} 


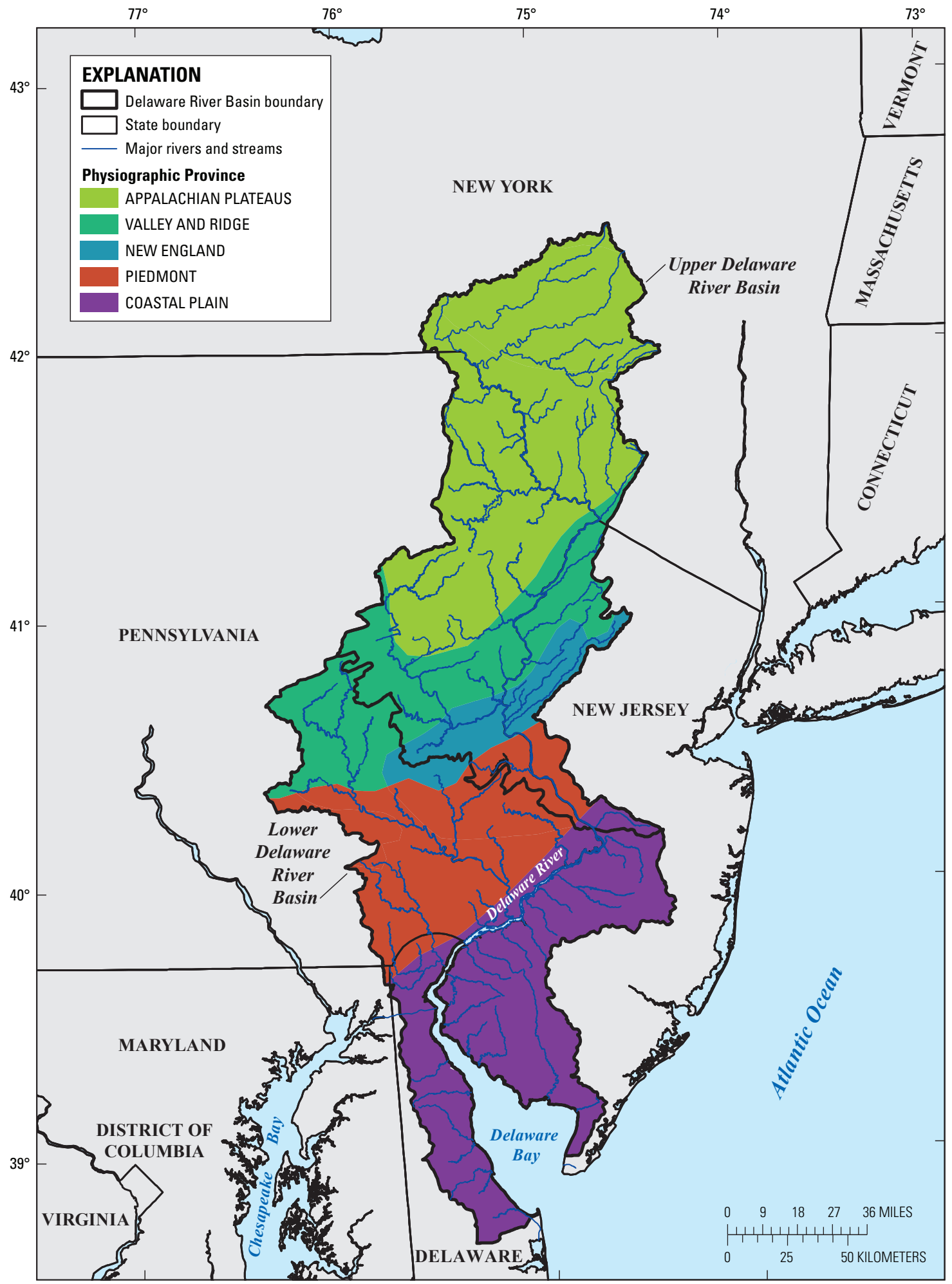

Base modified from U.S. Geological Survey 1:100,000-scale and 1:250,000-scale digital data

Figure 1. Physiographic provinces of the Delaware River Basin. 
Parameter-based regression equations used to predict streamflows at 22 exceedance probabilities from the flow-duration curve (FDC) for ungaged stream locations in the Delaware River Basin are presented. Flow-duration exceedance probabilities for 109 streamgages are presented. Streamflow data from continuous-record streamgages were used to develop correlation maps of the predicted correlation of streamflow between an ungaged stream location and a reference streamgage. A brief description of the Delaware River Basin Streamflow Estimator Tool (DRB-SET), a tool for estimating baseline and altered daily mean streamflow for ungaged stream locations in the Delaware River Basin, is presented.

\section{Estimation of Baseline Daily Mean Streamflow}

Daily mean streamflow can be estimated using the QPPQ method (Fennessey, 1994), which equates streamflow expressed as a percentile from the FDC for a particular day at an ungaged stream location with that from the FDC for the same day at a hydrologically similar gaged location where streamflow is measured (referred to as a "reference streamgage"). Streamflow corresponding to the flow-duration exceedance probability for the ungaged stream location are selected from a daily FDC constructed from points determined by regression equations. Geospatial correlation of streamflow, termed map correlation, (Archfield and others, 2010) is used to select a reference streamgage for the ungaged stream location. A graphical depiction of the QPPQ methodology is shown in figure 2 .

For this study, observed streamflow and basin characteristics from 109 reference streamgages (fig. 3) with unaltered streamflow were used to develop regression equations to predict streamflow corresponding to 22 exceedance probabilities from the FDC. The FDC for a reference streamgage is a cumulative frequency curve that shows the percentage of time that specified streamflows are equaled or exceeded (Searcy, 1960). It is constructed by arranging observed streamflow values for a given period of time by magnitude and the percentage of time observed daily streamflow values equaled or exceeded a specific streamflow. For this report, the term "exceedance probability" refers to the percentage of time that each streamflow value in the record is equaled or exceeded and is used when discussing statistics; the term "percentile" refers to an
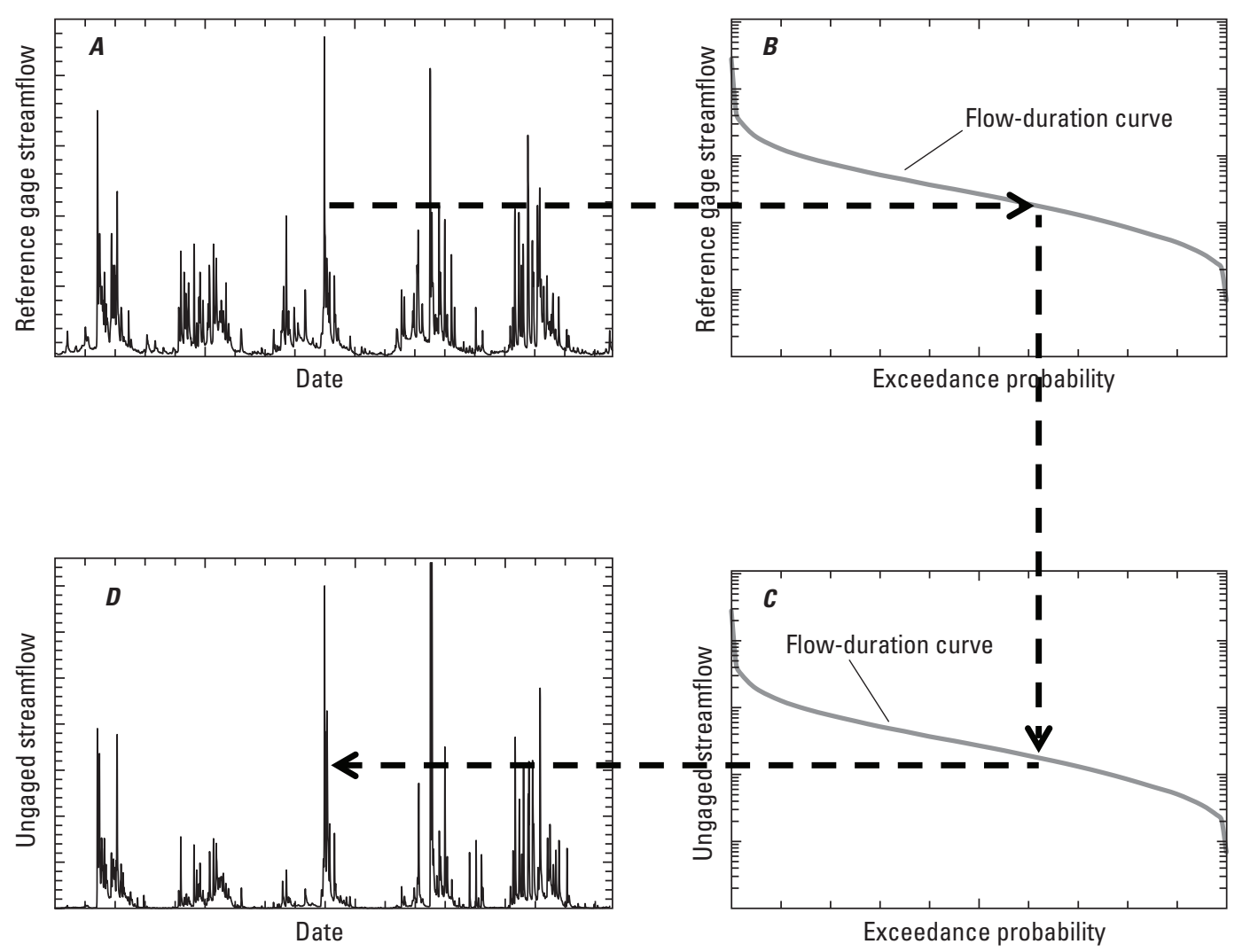

Figure 2. Graphical representation of the QPPQ methodology, showing $A$, observed daily mean streamflow at a reference streamgage, $B$, flow-duration curve at the reference streamgage, $C$, constructed flowduration curve at the ungaged stream location, and $D$, estimated daily mean streamflow at the ungaged stream location. (Modified from Archfield and others, 2010; Stuckey and others, 2014.) 


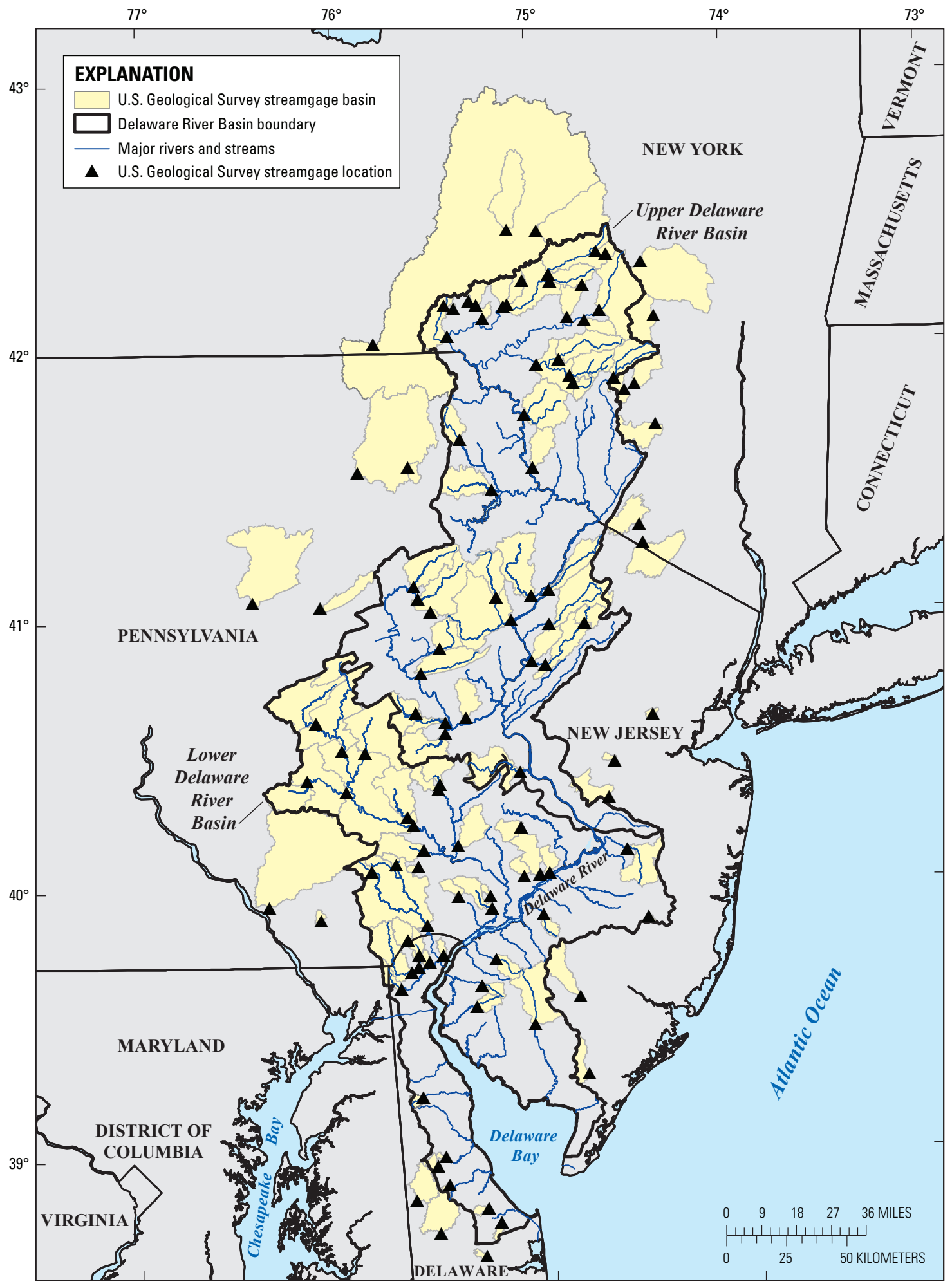

Base modified from U.S. Geological Survey 1:100,000-scale and 1:250,000-scale digital data

Figure 3. Location of U.S. Geological Survey reference streamgages in or near the Delaware River Basin. 
individual exceedance probability and is used when discussing methodology associated with a generic FDC.

The FDC for an ungaged stream location is constructed from estimates of streamflow. Streamflow at the ungaged stream location is estimated using the equivalent exceedance probabilities ( 22 percentiles for this study) from regression equations developed using basin characteristics and streamflow data from reference streamgages. Interpolation between exceedance probabilities of the 22 regression equations is used to determine all other streamflow percentiles. The conjunction of interpolation and regression equations yields a continuous daily hydrograph consisting of 18,628 streamflow values (one value for each day in water years 1960-2010) for the ungaged stream location.

A critical consideration in estimating baseline daily mean streamflow is the selection of the reference streamgage that results in the best estimate of daily streamflow at the ungaged stream location. Selection of a reference streamgage is performed in DRB-SET by default using map correlation (Archfield and others, 2010; Archfield and Vogel, 2010), although selection of the closest streamgage and selection by the user of a streamgage are also supported. Map correlation is a geostatistical procedure for determining the streamgage with streamflow that exhibits the strongest correlation with streamflow at an ungaged stream location.

\section{Reference Streamgages in the Delaware River Basin}

The streamflow at a reference streamgage constitutes a composite of the upstream land cover, geology, and hydrologic characteristics that can be used to represent ungaged basins with similar characteristics. Reference streamgages are used by water-resource managers for a variety of purposes, including regulatory decisions, drought and flood forecasting, and long-term baseline data collection. Data on observed streamflows at reference streamgages are used in this analysis to develop regression equations for estimating streamflows at 22 exceedance probabilities and for development of correlation maps.

\section{Reference Streamgage Criteria}

Reference streamgages selected for this analysis had streamflow that was minimally altered by regulation, diversion, mining, or other anthropogenic activities and had at least 10 years of continuous record. Substantial regulation for this analysis is defined by upstream reservoir impoundments that control at least 10 percent of the contributing drainage area at the streamgage. Information on diversions and mining effects were obtained from USGS Annual Water Data Reports, available online from 2006 through 2014 at http://wdr.water. usgs.gov/ and in paper format prior to 2006. Streamgages with questionable regulation in Pennsylvania were further evaluated graphically by comparing the range and median of the streamflows before and after construction of the impoundment and were evaluated statistically by using a two-sample Kolmogorov-Smirnov goodness of fit test (TIBCO Software Inc., 2008). If the results of this evaluation indicated that the streamflow at the streamgage was affected by regulation, the streamflow data were excluded from the overall analysis. The unaltered part of the record at streamgages that yield flow records altered by upstream regulation was included in the study if there was at least 10 years of unaltered flow before the impoundment was constructed. Streamgages outside of Pennsylvania were also reviewed for suitability as a reference streamgage by personnel in the respective USGS Water Science Center. There were 109 streamgages in or near the Delaware River Basin that met the above criteria-44 in Pennsylvania, 33 in New York, 17 in New Jersey, and 15 in Delaware (fig. 3). Of the 109 streamgages, 24 were outside the Delaware River Basin but were included for a more regional spatial coverage. The average number of years of record is 47 years for the 109 reference streamgages selected for use in this study. A complete listing of streamgages used in the analysis is presented in table 1.

The percentage of impervious area within a basin was used to identify streamgages with potential anthropogenic effects on streamflow (Fry and others, 2011). In most of the study area, baseline conditions were defined using data from reference streamgages with less than 10 percent of the upstream area covered by impervious surfaces. However, in large urban/suburban areas, such as in and around the Philadelphia/Camden, New Jersey area, some streamgages with a high percentage of impervious area were retained for improved spatial coverage. Historical maps indicate that much of the Philadelphia area has not undergone significant change in impervious area since the early 1900s (http://www. philageohistory.org/tiles/viewer/). The percent impervious area upstream from streamgages used in the analysis ranged from 0.0 to 32 percent, with 11 reference streamgages having more than 10 percent impervious area (fig. 4).

\section{Record Extension}

Estimation of daily mean streamflow using the QPPQ method for WY 1960-2010 for any ungaged stream location requires that all reference streamgages have a complete daily mean streamflow record for the same period. Of the 109 reference streamgages, 36 had a complete daily mean streamflow record with unaltered flow for the study period. The remaining streamgages had record lengths of 9-50 years during the study period. Streamflow records that were incomplete over the study period were extended to the complete period using the Streamflow Record Extension Facilitator (SREF) (Granato, 2009). The average number of years of record during the study period that required record extension was 24 years, with a range of 1-42 years (fig. 5). Estimated streamflow data from the record extension analysis were not used in the development of regression equations or correlation maps. 
Table 1. U.S. Geological Survey reference streamgages in and near the Delaware River Basin.

[USGS, U.S. Geological Survey; HUC8, 8-digit hydrologic unit code; water year, the 12-month period starting October 1, and ending September 30 of the following year]

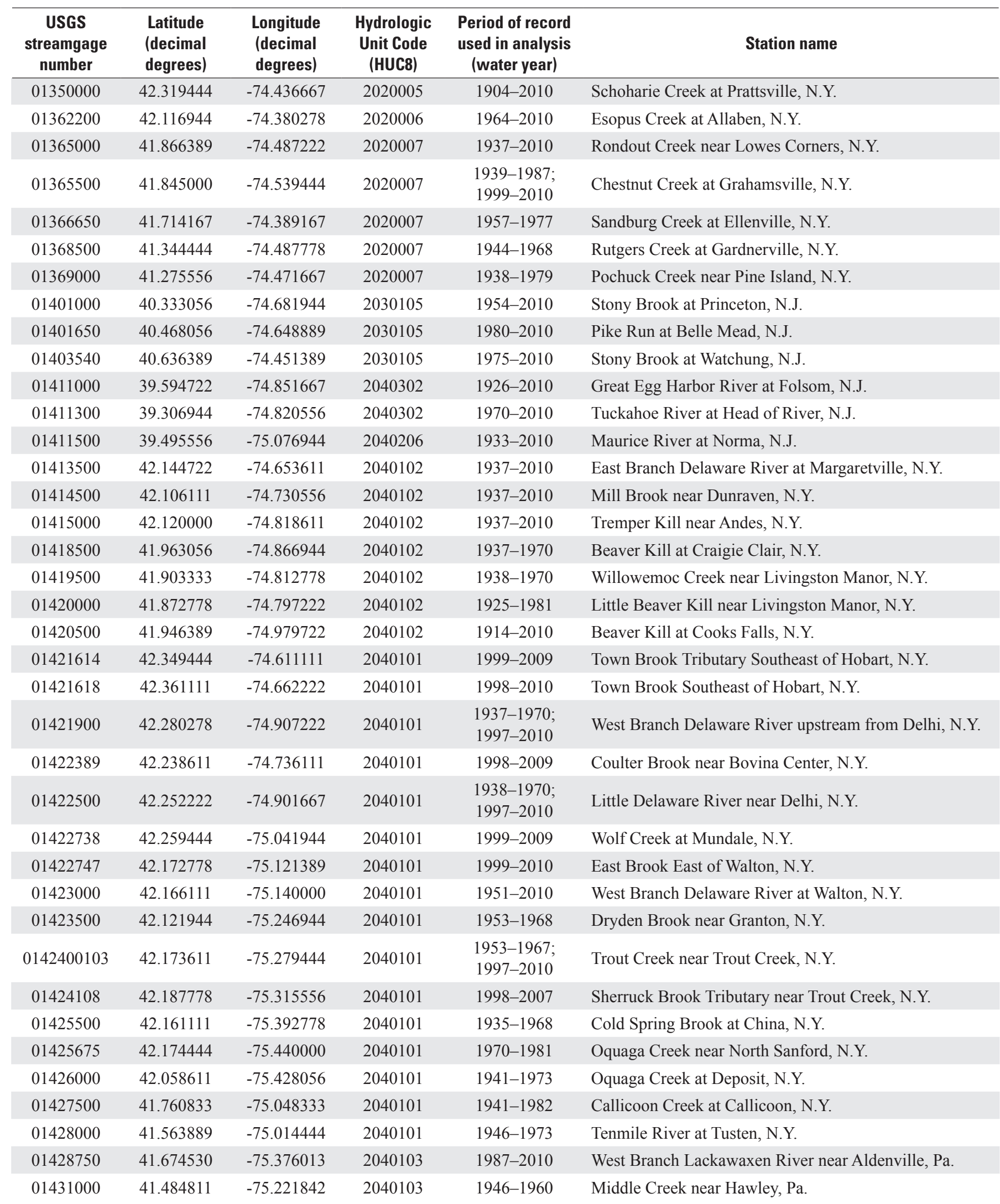


Table 1. U.S. Geological Survey reference streamgages in and near the Delaware River Basin.-Continued

[USGS, U.S. Geological Survey; HUC8, 8-digit hydrologic unit code; water year, the 12-month period starting October 1, and ending September 30 of the following year]

\begin{tabular}{|c|c|c|c|c|c|}
\hline $\begin{array}{c}\text { USGS } \\
\text { streamgage } \\
\text { number }\end{array}$ & $\begin{array}{l}\text { Latitude } \\
\text { (decimal } \\
\text { degrees) }\end{array}$ & $\begin{array}{l}\text { Longitude } \\
\text { (decimal } \\
\text { degrees) }\end{array}$ & $\begin{array}{c}\text { Hydrologic } \\
\text { Unit Code } \\
\text { (HUC8) }\end{array}$ & $\begin{array}{l}\text { Period of record } \\
\text { used in analysis } \\
\text { (water year) }\end{array}$ & Station name \\
\hline 01435000 & 41.890000 & -74.590000 & 2040104 & $1938-2010$ & Neversink River near Claryville, N.Y. \\
\hline 01439500 & 41.088151 & -75.037675 & 2040104 & 1909-2010 & Bush Kill at Shoemakers, Pa. \\
\hline 01440000 & 41.106111 & -74.952500 & 2040104 & $1924-2010$ & Flat Brook near Flatbrookville, N.J. \\
\hline 01440400 & 41.084815 & -75.214625 & 2040104 & $1958-2010$ & Brodhead Creek near Analomink, Pa. \\
\hline 01443500 & 40.980833 & -74.953333 & 2040105 & $1922-2010$ & Paulins Kill at Blairstown, N.J. \\
\hline 01445000 & 40.980833 & -74.776389 & 2040105 & $1940-2010$ & Pequest River at Huntsville, N.J. \\
\hline 01445500 & 40.830556 & -74.977778 & 2040105 & $1922-2010$ & Pequest River at Pequest, N.J. \\
\hline 01446000 & 40.843333 & -75.046389 & 2040105 & $1923-2010$ & Beaver Brook near Belvidere, N.J. \\
\hline 01449360 & 40.897592 & -75.502408 & 2040106 & $1967-2010$ & Pohopoco Creek at Kresgeville, Pa. \\
\hline 01450500 & 40.806205 & -75.597964 & 2040106 & $1940-2010$ & Aquashicola Creek at Palmerton, $\mathrm{Pa}$. \\
\hline 01451500 & 40.582320 & -75.482961 & 2040106 & $1946-2010$ & Little Lehigh Creek near Allentown, $\mathrm{Pa}$. \\
\hline 01451800 & 40.661762 & -75.626854 & 2040106 & $1967-2010$ & Jordan Creek near Schnecksville, Pa. \\
\hline 01452000 & 40.623153 & -75.482405 & 2040106 & $1945-2010$ & Jordan Creek at Allentown, Pa. \\
\hline 01452500 & 40.641209 & -75.379347 & 2040106 & $1949-2010$ & Monocacy Creek at Bethlehem, Pa. \\
\hline 01459500 & 40.433715 & -75.116561 & 2040105 & $1936-1973$ & Tohickon Creek near Pipersville, Pa. \\
\hline 01464500 & 40.137222 & -74.600000 & 2040201 & $1938-2010$ & Crosswicks Creek at Extonville, N.J. \\
\hline 01464907 & 40.229275 & -75.119616 & 2040201 & $1999-2010$ & Little Neshaminy Creek at Valley Road, Pa. \\
\hline 01470500 & 40.522593 & -75.998268 & 2040203 & $1948-2008$ & Schuylkill River at Berne, Pa. \\
\hline 01470756 & 40.514261 & -75.882982 & 2040203 & $1974-1995$ & Maiden Creek at Virginville, $\mathrm{Pa}$. \\
\hline 01470779 & 40.413426 & -76.171613 & 2040203 & $1975-2008$ & Tulpehocken Creek near Bernville, Pa. \\
\hline 01471000 & 40.368982 & -75.979102 & 2040203 & $1951-1978$ & Tulpehocken Creek near Reading, Pa. \\
\hline 01471980 & 40.272873 & -75.679910 & 2040203 & $1975-2004$ & Manatawny Creek near Pottstown, Pa. \\
\hline 01472000 & 40.241763 & -75.651575 & 2040203 & $1928-1978$ & Schuylkill River at Pottstown, Pa. \\
\hline 01472157 & 40.151491 & -75.601305 & 2040203 & $1969-2008$ & French Creek near Phoenixville, $\mathrm{Pa}$. \\
\hline 01472174 & 40.089548 & -75.630203 & 2040203 & $1967-1983$ & Pickering Creek near Chester Springs, Pa. \\
\hline 01472198 & 40.393988 & -75.515459 & 2040203 & $1982-2008$ & Perkiomen Creek at East Greenville, Pa. \\
\hline 01472199 & 40.373988 & -75.522403 & 2040203 & $1982-2008$ & West Branch Perkiomen Creek at Hillegass, Pa. \\
\hline 01473120 & 40.164550 & -75.433239 & 2040203 & $1967-1994$ & Skippack Creek near Collegeville, Pa. \\
\hline
\end{tabular}


Table 1. U.S. Geological Survey reference streamgages in and near the Delaware River Basin.-Continued

[USGS, U.S. Geological Survey; HUC8, 8-digit hydrologic unit code; water year, the 12-month period starting October 1, and ending September 30 of the following year]

\begin{tabular}{|c|c|c|c|c|c|}
\hline $\begin{array}{c}\text { USGS } \\
\text { streamgage } \\
\text { number }\end{array}$ & $\begin{array}{l}\text { Latitude } \\
\text { (decimal } \\
\text { degrees) }\end{array}$ & $\begin{array}{l}\text { Longitude } \\
\text { (decimal } \\
\text { degrees) }\end{array}$ & $\begin{array}{l}\text { Hydrologic } \\
\text { Unit Code } \\
\text { (HUC8) }\end{array}$ & $\begin{array}{l}\text { Period of record } \\
\text { used in analysis } \\
\text { (water year) }\end{array}$ & Station name \\
\hline 01475510 & 39.929002 & -75.272406 & 2040202 & $1965-1990$ & Darby Creek near Darby, Pa. \\
\hline 01475530 & 39.974835 & -75.279907 & 2040202 & $1965-2008$ & Cobbs Creek at U.S. Highway No. 1 at Philadelphia, Pa. \\
\hline 01475850 & 39.976499 & -75.436586 & 2040202 & 1982-2008 & Crum Creek near Newtown Square, Pa. \\
\hline 01477120 & 39.740556 & -75.259167 & 2040202 & $1967-2010$ & Raccoon Creek near Swedesboro, N.J. \\
\hline 01477800 & 39.760972 & -75.518694 & 2040205 & $1945-2010$ & Shellpot Creek at Wilmington, Del. \\
\hline 01478000 & 39.637389 & -75.727889 & 2040205 & 1943-2010 & Christina River at Coochs Bridge, Del. \\
\hline 01479000 & 39.699222 & -75.675028 & 2040205 & 1932-2010 & White Clay Creek near Newark, Del. \\
\hline 01479820 & 39.816777 & -75.691601 & 2040205 & 1988-2008 & Red Clay Creek near Kennett Square, Pa. \\
\hline 01480000 & 39.762806 & -75.636500 & 2040205 & $1943-2010$ & Red Clay Creek at Wooddale, Del. \\
\hline 01480015 & 39.715750 & -75.639944 & 2040205 & 1989-2010 & Red Clay Creek near Stanton, Del. \\
\hline 01480100 & 39.734835 & -75.586869 & 2040205 & 1964-1981 & Little Mill Creek at Elsmere, Del. \\
\hline 01480300 & 40.072879 & -75.860774 & 2040205 & 1961-2008 & West Branch Brandywine Creek near Honey Brook, Pa. \\
\hline 01480675 & 40.097879 & -75.741599 & 2040205 & $1967-2008$ & Marsh Creek near Glenmoore, Pa. \\
\hline 01481000 & 39.869833 & -75.593262 & 2040205 & $\begin{array}{c}\text { 1912-1953; } \\
1963-1973\end{array}$ & Brandywine Creek at Chadds Ford, Pa. \\
\hline 01482500 & 39.643889 & -75.330278 & 2040206 & $\begin{array}{l}1941-1984 \\
2002-2010\end{array}$ & Salem River at Woodstown, N.J. \\
\hline 01483000 & 39.565556 & -75.360556 & 2040206 & $1953-1972$ & Alloway Creek at Alloway, N.J. \\
\hline 01483500 & 39.232889 & -75.632150 & 2040207 & $1943-1975$ & Leipsic River near Cheswold, Del. \\
\hline 01484000 & 38.975947 & -75.567147 & 2040207 & 1932-2009 & Murderkill River near Felton, Del. \\
\hline 01484100 & 38.905778 & -75.512750 & 2040207 & 1958-2010 & Beaverdam Branch at Houston, Del. \\
\hline 01484270 & 38.761501 & -75.267134 & 2040207 & 1971-2005 & Beaverdam Creek near Milton, Del. \\
\hline 01484300 & 38.814279 & -75.327137 & 2040207 & $1957-1978$ & Sowbridge Branch near Milton, Del. \\
\hline 01484500 & 38.638861 & -75.341972 & 2060010 & 1943-2004 & Stockley Branch at Stockley, Del. \\
\hline 01487000 & 38.728333 & -75.561861 & 2060008 & 1935-2010 & Nanticoke River near Bridgeville, Del. \\
\hline 01488500 & 38.849694 & -75.673111 & 2060008 & $\begin{array}{l}1935-2003 \\
2005-2010\end{array}$ & Marshyhope Creek near Adamsville, Del. \\
\hline 01498500 & 42.445000 & -74.963611 & 2050101 & 1938-1975 & Charlotte Creek at West Davenport, N.Y. \\
\hline 01499000 & 42.450833 & -75.114722 & 2050101 & $1941-1968$ & Otego Creek near Oneonta, N.Y. \\
\hline 01503000 & 42.035278 & -75.803056 & 2050101 & 1913-2010 & Susquehanna River at Conklin, N.Y. \\
\hline 01533950 & 41.574802 & -75.641855 & 2050106 & 1961-1978 & South Branch Tunkhannock Creek near Montdale, Pa. \\
\hline 01534000 & 41.558410 & -75.894642 & 2050106 & 1914-2010 & Tunkhannock Creek near Tunkhannock, Pa. \\
\hline 01538000 & 41.059250 & -76.093540 & 2050107 & 1920-2010 & Wapwallopen Creek near Wapwallopen, Pa. \\
\hline 01539000 & 41.078141 & -76.431056 & 2050107 & $1936-2010$ & Fishing Creek near Bloomsburg, Pa. \\
\hline 01576754 & 39.946489 & -76.367739 & 2050306 & $1985-2010$ & Conestoga River at Conestoga, Pa. \\
\hline 01578400 & 39.894826 & -76.113564 & 2050306 & 1963-1981 & Bowery Run near Quarryville, Pa. \\
\hline
\end{tabular}




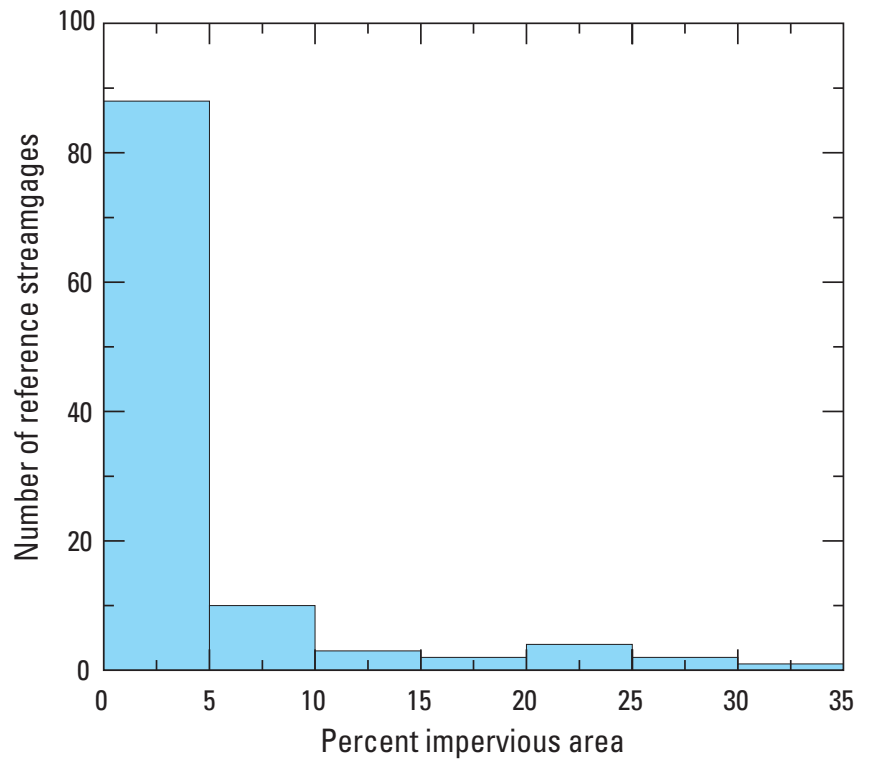

Figure 4. Histogram showing percent impervious area in the reference streamgage subbasins within the Delaware River Basin.

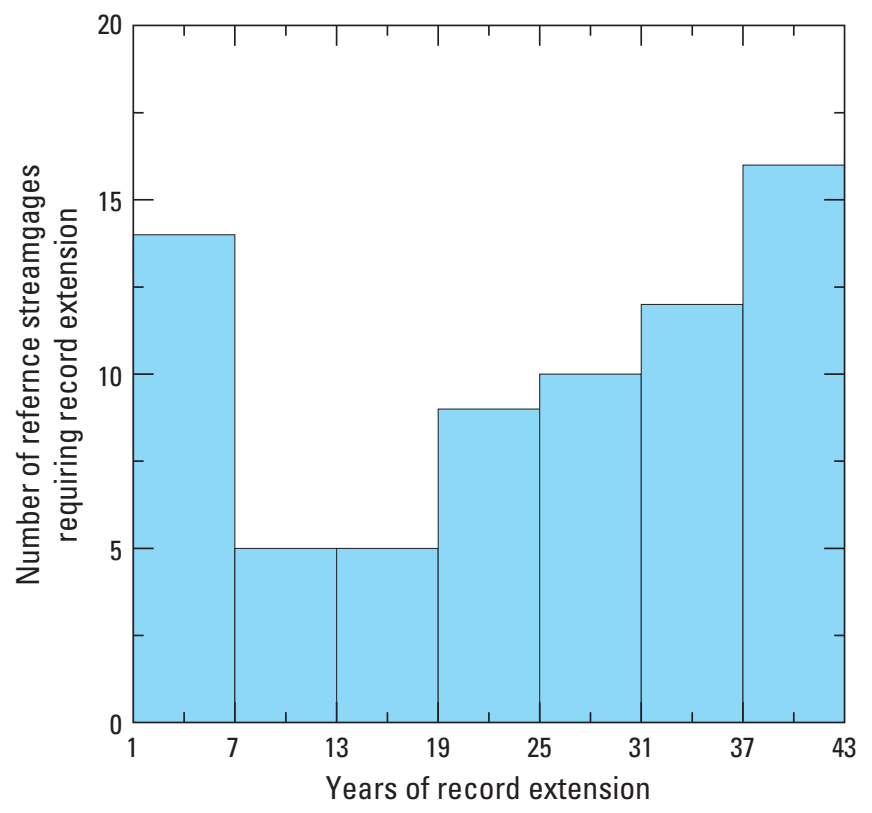

Figure 5. Histogram showing the number of reference streamgages requiring record extension and the number of years of record extension, Delaware River Basin.
The methodology used for the SREF relies on the assumption that long-term streamflow records from hydrologically similar streamgages can be used to estimate missing record for a streamgage of interest (Granato, 2009). The SREF program produces estimated daily mean streamflow for the purpose of extending or augmenting the streamflow record at streamgages with limited data (Granato, 2009). Record extension in SREF uses the line of organic correlation (LOC) regression as part of the maintenance of variance (MOVE) method. A valuable characteristic of the LOC for streamflow record extension is the prediction of flows with variance and probability distribution that can closely estimate those of the observed record (Helsel and Hirsch, 2002). The MOVE.1 method (Hirsch, 1982) was used for this analysis.

The daily mean streamflows were log transformed prior to LOC regression. This transformation resulted in undefined logarithms when zero-flow values were present. SREF offers four options to address zero flows in the streamflow record. Three of the options substitute constants for zero-flow days. The fourth option applies a streamflow-recession constant beginning with the last nonzero streamflow value prior to the zero-flow sequence. This option was selected for the analysis of the reference streamgages to avoid imposing an arbitrary constant flow value over a potentially substantial period of low-flow values that would result in a flat line hydrograph for streamgages at their zero-flow threshold. A recession constant of 0.9 was selected on the basis of prior sampling of low-flow recession rates in Pennsylvania (Stuckey and others, 2014).

The streamgages used to extend the record of a streamgage with an incomplete period of record during WY 1960-2010 are termed "index streamgages." Ten years was considered the minimum streamflow record length for an acceptable application of MOVE.1. A maximum of three streamgages was used for record extension to cover the incomplete study period (Appendix 1). Selection of index streamgages was based on period of available concurrent record, strength of correlation, and distribution of LOC residuals (Granato, 2009). Record prior to 1960 was used when necessary to establish the relation between streamgages with an incomplete period of record and the index streamgage. The concurrent records were evaluated graphically and statistically using correlation to ensure a good fit between the index streamgage and a streamgage with an incomplete period of record. Record extension correlations ranged from 0.742 to 0.988 , with a mean of 0.894 . A maximum correlation of 1.0 indicates a perfect linear relation. A listing of streamgages with record extension techniques applied is provided in Appendix 1.

\section{Regression Equations for Estimating Streamflow at Flow-Duration Exceedance Probabilities}

Regression equations were developed for 22 percentiles along the FDC using observed streamflow data from reference streamgages in and near the Delaware River Basin from 
the beginning of observed record through WY 2010. Values for basin characteristics with possible effects on a range of streamflows, such as land cover and soil properties, were determined for the streamgages, and exceedance probabilities were computed for the streamgages using the entire period of unaltered flow. The observed exceedance probability discharges (dependent variable) were related to the basin characteristics (independent or explanatory variables) using regression techniques.

\section{Flow-Duration Exceedance Probabilities and Basin Characteristics for Reference Streamgages}

Daily streamflow values for the selected reference streamgages were retrieved from the National Water Information System web application (NWISWeb) (http:// waterdata.usgs.gov/nwis) using the program Get NWIS WEB Streamflow Files (GNWISQ) (Granato, 2009). This program allows for batch downloads from NWISWeb and formats the retrieved files for further analysis. After the downloaded data were reviewed for completeness and accuracy, the data were entered into the Make Plotting Position File (MkPP) (Granato, 2009) to compute the flow-duration exceedance probabilities. The governing equations and statistical methods utilized in MkPP are documented by Granato (2009). The Weibull plotting position option was used. Only the period of record for observed unaltered flow at the reference streamgage was used to compute the exceedance probabilities for use in the regression analysis. No extended streamflow record was used to compute the exceedance probabilities.

A list of 43 climatologic, geologic, hydrologic, and physiographic basin characteristics with possible effects on a range of streamflows was compiled from various geographic information system (GIS) sources (table 2). Only basin characteristics derived using GIS methods were evaluated during the regression analysis. The use of GIS-derived basin characteristics improves the consistency, reproducibility, and ease-of-use of the resulting regression equations. National datasets were emphasized and utilized whenever available to limit issues pertaining to State and local boundaries.

\section{Regression Analysis and Resulting Flow- Duration Exceedance Probability Regression Equations}

The exceedance probability discharges for observed streamflows were related to basin characteristics using exploratory ordinary least squares (OLS) and weighted least squares (WLS) regression techniques. The exceedance probabilities associated with each reference streamgage were weighted using the following expression for the WLS regression techniques to account for differing periods of record: (number of years of record at streamgage*number of streamgages)/sum of years of record of all streamgages. Regression analyses were performed using the statistical package Spotfire S+ (TIBCO Software Inc., 2008). Regression diagnostics used to evaluate the resulting regressions included graphical relations, multicollinearity, prediction error sum of squares (PRESS) statistic, standard error, and coefficient of determination $\left(\mathrm{R}^{2}\right)$ (Helsel and Hirsch, 2002).

Streamflow data from reference streamgages in and near the Delaware River Basin were used to develop regression equations for estimating the 1-, 2-, 5-, 10-, 15-, 20-, 25-, 30-, 40-, 50-, 60-, 70-, 75-, 80-, 85-, 90-, 95-, 98-, and 99-percent exceedance probability discharges (designated as $\mathrm{P} 1, \mathrm{P} 2$, P5, P10, P15, P20, P25, P30, P40, P50, P60, P70, P75, P80, $\mathrm{P} 85, \mathrm{P} 90, \mathrm{P} 95, \mathrm{P} 98$, and $\mathrm{P} 99$, respectively). Two additional regression equations were developed for the 0.0054 - and 99.9946-percent flow-duration exceedances (P0.0054 and P99.9946, respectively) to represent the ends of the FDC for the period from 1960 to 2010 (51 years), and an equation was developed for the 99.95-percent flow-duration exceedance (P99.95) to further define the low end of the FDC. Because only observed data were used in the regression analysis and those extreme exceedances require additional years of record (data points) to compute, the streamgages used to develop the regression equations for the lower and upper ends of the FDC were limited to those with at least 51 years of record. As a result, 40 streamgages had a sufficient period of record, regardless of whether this period was contained within the study period, and were used to develop regression equations for estimating the P0.0054, P99.9946, and P99.95 exceedance probability discharges.

Outliers and streamgages with high leverage and (or) influence were removed from an individual regression analysis only if sufficient data or information were found to support the removal of the streamgages, such as high water use in the basin (including withdrawals and discharges), basin characteristic or streamflow values well outside the normal or expected range for that variable, or poor or estimated daily streamflow computations during low- or high-flow periods. Three streamgages with a P99.9946 exceedance probability discharge equaling zero and one streamgage with a P99.95 exceedance probability discharge equaling zero were excluded from the regression analysis for those particular exceedance probabilities.

During exploratory regression analysis, regression models were developed for the entire basin using different regions that were based on physiographic province, hydrologic unit code (HUC) 8 boundaries, and residual standard errors. The results of these models were then compared to each other using standard errors, coefficient of determination $\left(\mathrm{R}^{2}\right)$, residuals, PRESS statistic, and other regression diagnostics. Insufficient data were available, owing to the small number of streamgages in some physiographic provinces, to develop robust regression models by region that would have adequately predicted streamflows for all 22 exceedance probabilities, even when some physiographic provinces were combined to make larger regions. The basin-wide regression model 
Table 2. Basin characteristics used in the development of regression equations for flow-duration exceedance probabilities for streams in the Delaware River Basin.

[>, greater than]

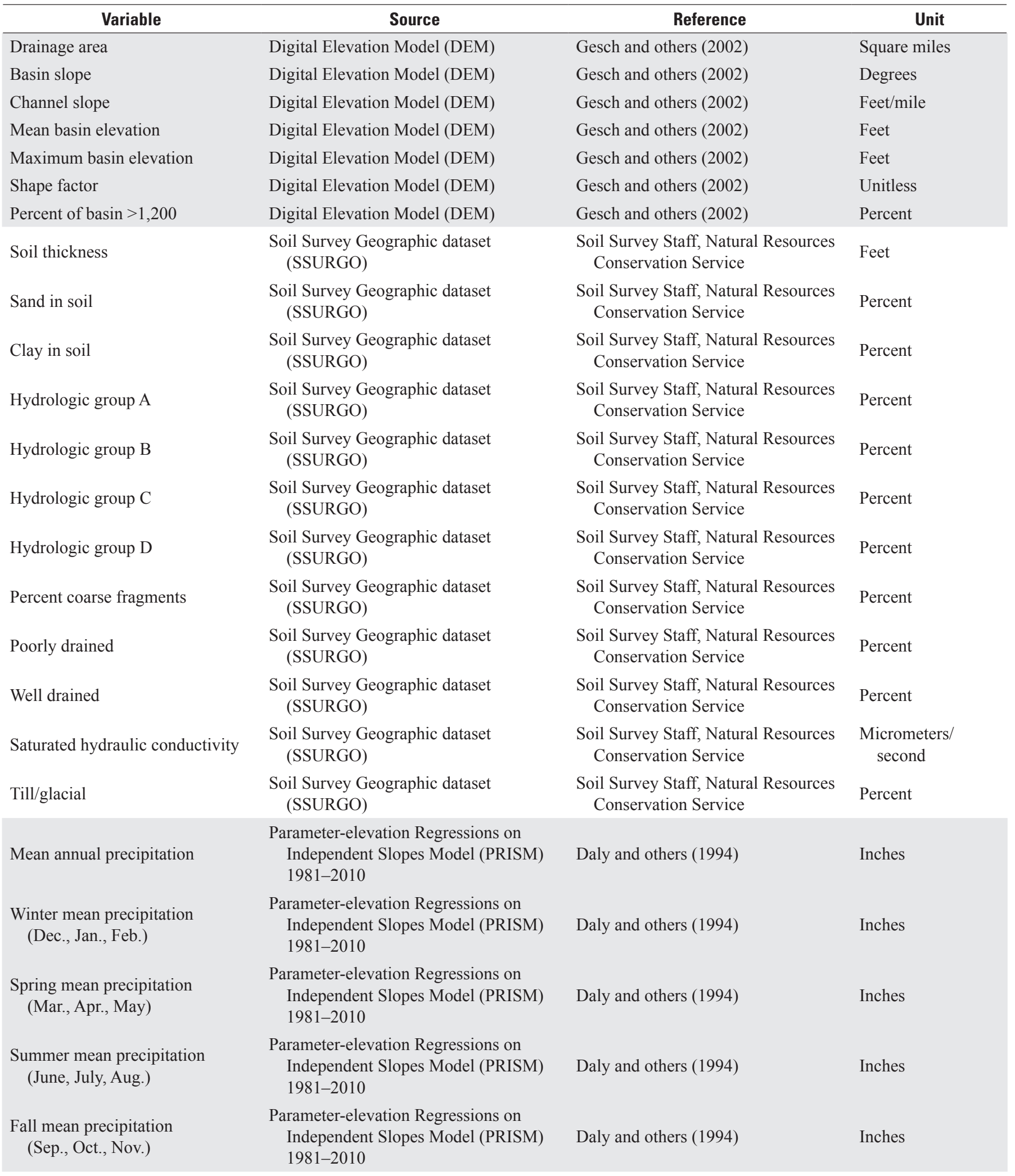


Table 2. Basin characteristics used in the development of regression equations for flow-duration exceedance probabilities for streams in the Delaware River Basin.-Continued

[>, greater than]

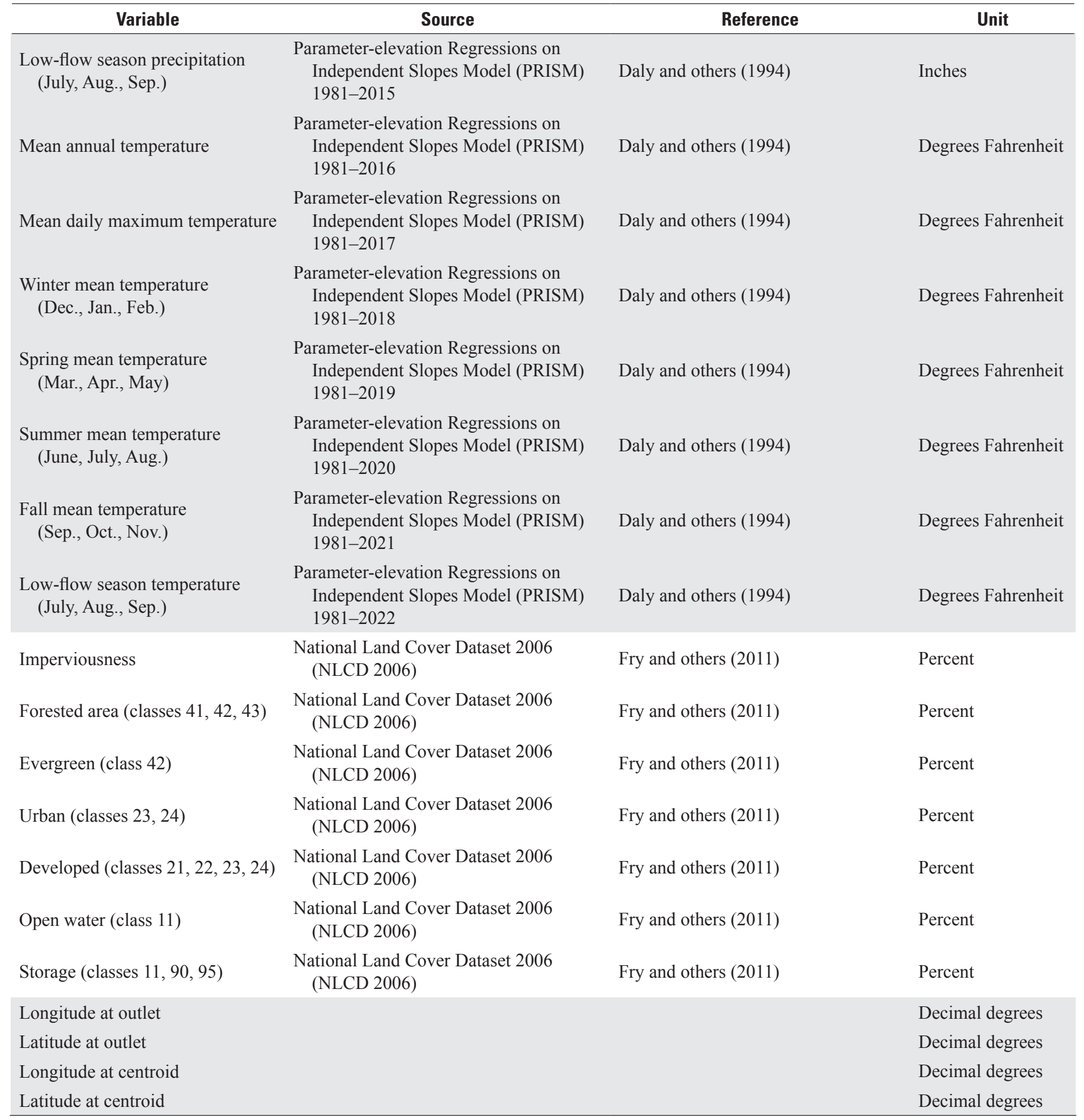


performed as well as, if not better than, the other regionalization models generated during the exploratory analysis, and it was used to develop the suite of 22 exceedance probability regression equations. WLS was used to generate the final basin-wide regression equations.

The following independent variables were found to be significant at the 95-percent confidence level for one or more regression equations: latitude at the outlet, drainage area, mean annual precipitation (1981-2010), mean winter precipitation (December-February; 1981-2010), saturated hydraulic conductivity, and percentages of poorly drained soil and sand in soil (table 3). The values for basin characteristics associated with the streamgages used in the analysis are listed in Appendix 2. To form a near-linear relation between the flowduration exceedance probabilities and basin characteristics, all independent and dependent variables were log-transformed (base 10) prior to regression analysis. Because percentages can have a value of zero, a value of 1.0 was added to the decimal form of the percentages of poorly drained soil and sand in soil before the variables were log transformed.

The regression model took the following form, in log units:

$$
\begin{aligned}
& \log \widehat{Q}_{p}=A+b \log D A+c \log L a t+d \log P P T . A N N \\
& +e \log P P T . W I N+f \log (1+.01 * P O O R) \\
& +g \log (1+.01 * S A N D)+h \log (K S A T)
\end{aligned}
$$

or in arithmetic space:

$$
\begin{aligned}
& \widehat{Q}_{p}=10^{A}(\text { DA })^{b}(\text { Lat })^{c}(\text { PPT.ANN })^{d}(\text { PPT.WIN })^{e} \\
& (1+.01 * P O O R)^{f}(1+.01 * S A N D)^{g}(\text { KSAT })^{h}
\end{aligned}
$$

where

$\log \quad=\log$ to base 10

$\widehat{Q}_{p} \quad=$ discharge at flow-duration exceedance probability, in cubic feet per second $\left(\mathrm{ft}^{3} / \mathrm{s}\right)$;

$A \quad=$ the intercept, estimated by WLS;

$D A \quad=$ drainage area, in square miles;

Lat = latitude of the outlet of the basin, in decimal degrees;

PPT.ANN = mean annual precipitation, in inches;

$P P T . W I N=$ mean winter precipitation, in inches;

$P O O R=$ poorly drained soil, in percent;

SAND = sand in soil, in percent;

KSAT = saturated hydraulic conductivity, in micrometers per second; and

$b, c, d, e, f$, $g$, and $h$

The coefficients for the resulting regression equations are listed in table 3 . All basin characteristic coefficients were checked for continuity issues and expected effect on flow. Generally, the coefficients did not have any continuity issues,

except where changes occurred to the suite of regressions or where exceedances were closer together than elsewhere along the FDC. These continuity issues did not appear to affect the performance of the regressions. All basin characteristic coefficients reflected expected signage, and resulting changes to streamflow were reasonable. For example, as the percentage of poorly drained soil increased, discharge decreased for low and medium flows; for high flows, as the percentage of poorly drained soil increased, discharge also increased. This is because for low and medium flows, water infiltrating through the poorly drained soils is hindered from entering the groundwater, which would result in a lower base-flow contribution to the stream. During high flows, the poorly drained soil acts as an impervious surface, increasing overland flow and runoff, which would result in higher streamflows.

Flow-duration exceedance probability discharges computed from streamflow data (observed) and regression equations (predicted) for streamgages used in the regression analysis are listed in Appendix 3. The predicted exceedance probability discharges computed from the regression equations for the reference streamgages were checked for continuity, and no issues or problems were found.

Standard errors of prediction (Helsel and Hirsch, 2002) for regression equations provide an estimate of reliability of the predicted variable, in this case, streamflow at 22 exceedance probabilities (table 3 ). The standard error of prediction is a measure of the average accuracy of the regression equations when predicting values for ungaged stream locations; about two-thirds of the regression estimates for ungaged stream locations will have errors less than the average standard errors of prediction given for the equations (Ries, 2007). The standard error of prediction for the flow-duration exceedance probability regression equation ranges from 0.05 to 0.30 in log units (11 percent to 79 percent; table 3); median and mean standard error over the entire suite of flow-duration equations is 24 and 32 percent, respectively. The regression equations used to estimate the lower ends of the FDC have the highest errors; the extreme low-flow exceedance probability of P99.9946 has an error of 79 percent, and P99.95 and P99 have errors of 69 percent and 64 percent, respectively. Regressions to estimate extreme low-flow statistics typically have higher associated errors because low flows are dependent on multifaceted factors such as underlying geology and evapotranspiration, which can be difficult to capture as independent parameters in a regression model.

The coefficient of determination $\left(\mathrm{R}^{2}\right)$ provides a way to estimate the uncertainty associated with the regression. For example, the $\mathrm{R}^{2}$ for $\mathrm{P} 60$ is 0.98 , indicating the basin characteristics selected for use in the P60 regression equation accounted for 98 percent of the variability in streamflow for the 60-percent exceedance value (table 3). A lower $\mathrm{R}^{2}$ for P99.9946 (0.81) indicates that other variables may help to better define this extreme low-flow prediction. Multicollinearity between the basin characteristics was evaluated for significance in each regression equation using variance inflation factor (VIF) and correlation. The maximum VIF between the independent variables is 1.5 , and the maximum correlation is 0.5 , indicating no issues with multicollinearity. 


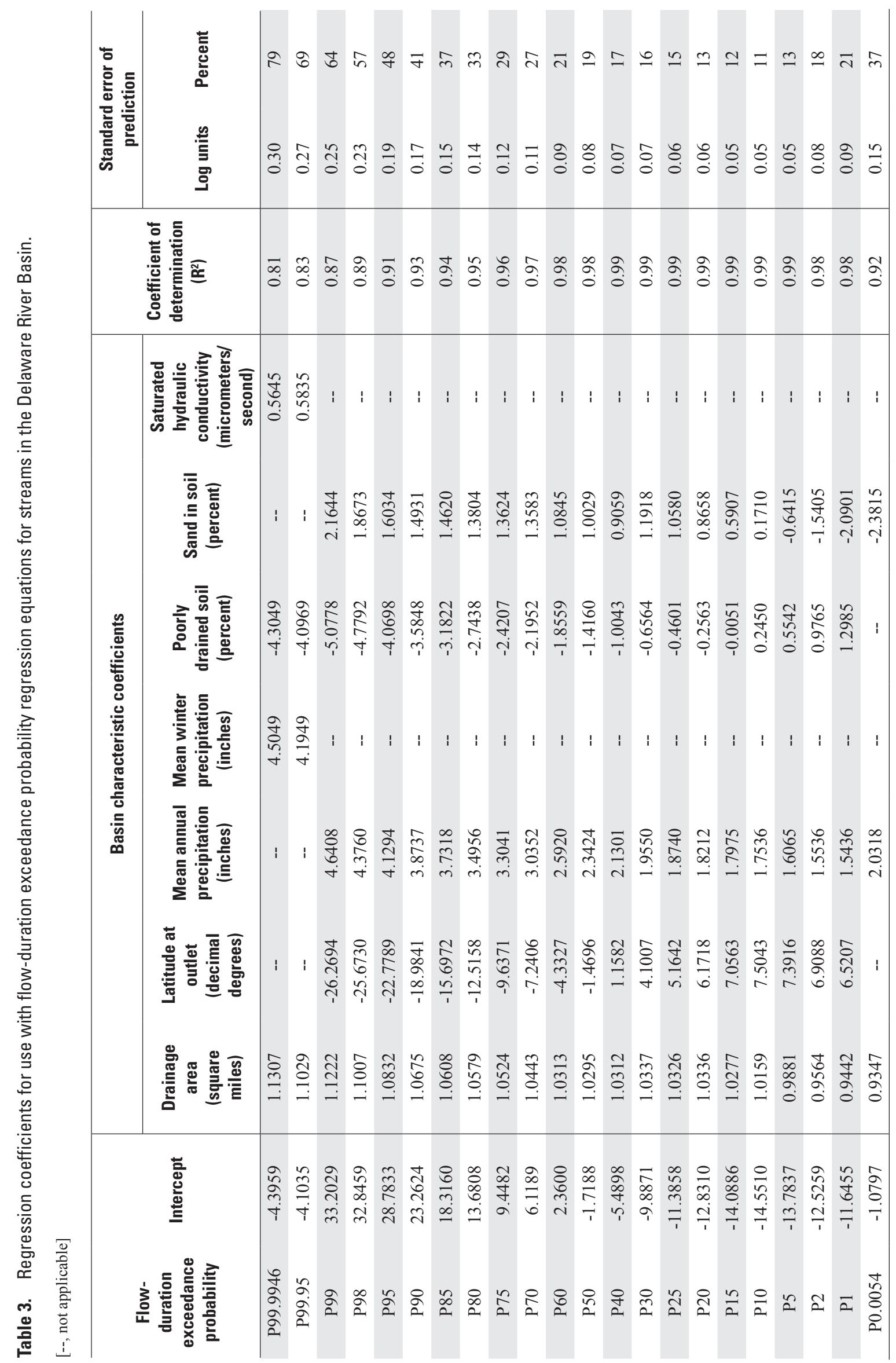




\section{Selection of Reference Streamgages for Estimating Daily Mean Streamflow}

An important consideration in applying the QPPQ method is the selection of a reference streamgage. A traditional approach has been to select the closest streamgage to the ungaged stream location as the representative reference gage. Choosing the closest streamgage as the most appropriate reference streamgage is based on the assumption that similarity in the conditions determining streamflow increases with decreasing distance between two locations (Stuckey and others, 2014). However, there are instances where conditions at the closest streamgage are neither physically nor hydrologically similar to those at the ungaged stream location. Map correlation based on kriging is an alternative to using the closest reference streamgage (Archfield and Vogel, 2010). These methods for selecting a reference streamgage were compared using observed streamflow correlations to indicate what the "best," or most appropriate representative reference streamgage should be.

\section{Closest Streamgage}

The closest reference streamgage approach was evaluated to determine how successful the method was in selecting the reference streamgage with streamflows most highly correlated to those of the ungaged stream location. The closest reference streamgage was defined as the streamgage with the shortest distance from the centroid of the basin of the reference streamgage to the outlet of the ungaged stream location; this method was found to perform best in Pennsylvania by Stuckey and others (2014). Observed streamflow correlations using Spearman's rho were calculated among the 86 streamgages within the Delaware River Basin to evaluate whether using the closest streamgage identifies the most appropriate, or best, streamgage. The reference streamgage with the highest observed correlations and shortest distance to the ungaged stream location was the same 48 percent of the time, and 94 percent of the time, the closest streamgage was in the top five streamgages.

\section{Map Correlation}

Map correlation is a geostatistical approach to selecting a reference streamgage where streamflow exhibits the strongest correlation with streamflow at an ungaged stream location. First, each reference streamgage is assigned a unique map of correlation estimates developed from a model of the spatial correlation structure, or variogram, between it and all other available reference streamgages in and near the Delaware River Basin (fig. 6). Ordinary kriging (Isaaks and Srivastava, 1989) is used to estimate the predicted correlation at the ungaged stream location.

Selection of the most appropriate representative reference streamgage is accomplished using the map correlation method by choosing the streamgage whose map has the highest estimated correlation coefficient at the coordinates of the ungaged stream location. Map correlation may be a unique application of geostatistical models in that many models need to be compared as part of the reference streamgage selection process. Selecting the best model is dependent in part on all models being fit in a consistent manner to avoid biasing one or more models. Variogram model fitting can involve a substantial amount of trial and error (Isaaks and Srivastava, 1989; Archfield and Vogel, 2010) and subjectivity. When the models are fit interactively, it is likely to result in many parameters having few similarities. One model may perform better than another simply because more time was given to finding the best parameters. Considering the small differences in correlation coefficients among many reference streamgages, minimization of subjectivity in model fitting is an important consideration.

Variogram models were developed for 109 reference streamgages in and near the Delaware River Basin with minimally altered streamflow and at least 10 years of continuous record during WY1960-2010. In an attempt to minimize subjectivity, the variogram models were developed in the Free R Software (http://www.r-project.org/) using default automated parameter estimation. The spherical variogram model was used to describe the spatial structure within the correlation of daily streamflow. Spearman's rho, a non-parametric rankbased correlation coefficient, was used to define the correlation between the reference streamgages. Stuckey and others (2014) found that Spearman's rho performed as well as if not better than Kendall's tau in two pilot basins in Pennsylvania. All reference streamgage correlations used in the variogram development were significant at the 0.05 level.

Map correlation results were evaluated to determine how accurately map correlation reproduced the correlation coefficient for the reference streamgages and how often the streamgage with the highest estimated correlation was the same as the streamgage with the highest observed correlation. Observed and estimated correlations among streamgages were compared for goodness of fit to evaluate the effectiveness of the map correlation model. Root mean square error (RMSE) values between the observed and estimated streamflow correlations were computed for each of the streamgages using observed and estimated correlations. RMSE values ranged from 0.031 to 0.081 with a median value of 0.048 (fig. 7). When plotted spatially (fig. 7), the highest RMSE values (values within the upper quartile range) were generally in the northern and central parts of the basin, whereas the lowest RMSE values were found in south-central part of the basin. This does not necessarily dictate how map correlation overall will perform, but shows how well the correlation coefficient at each reference streamgage was reproduced. The correlations for the 86 streamgages within the Delaware River Basin were also evaluated to determine whether the same streamgage had the highest observed and estimated correlations. Streamgages had the highest observed and estimated correlations 30 percent of the time, and streamgages with the highest observed correlation were within the top five estimated correlations 80 percent of the time. Although these percentages are lower than those found using the closest streamgage, variations of the correlation coefficients for many streamgages with the highest correlations were quite small, on the order of magnitude 0.001 . 


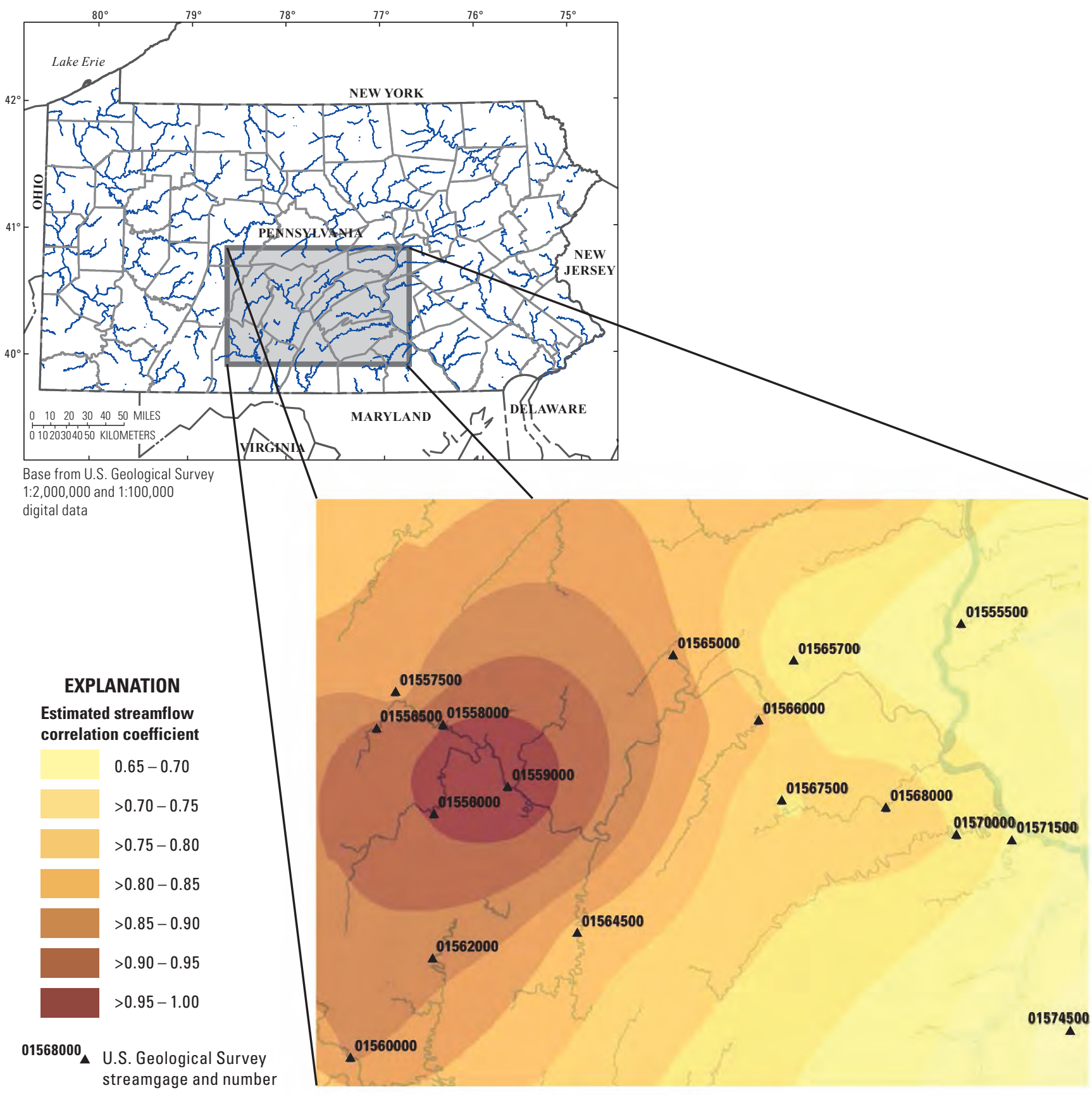

Figure 6. Example streamflow correlation map for U.S. Geological Survey streamgage 01559000, Juniata River at Huntingdon, Pa. (from Stuckey and others, 2014). 


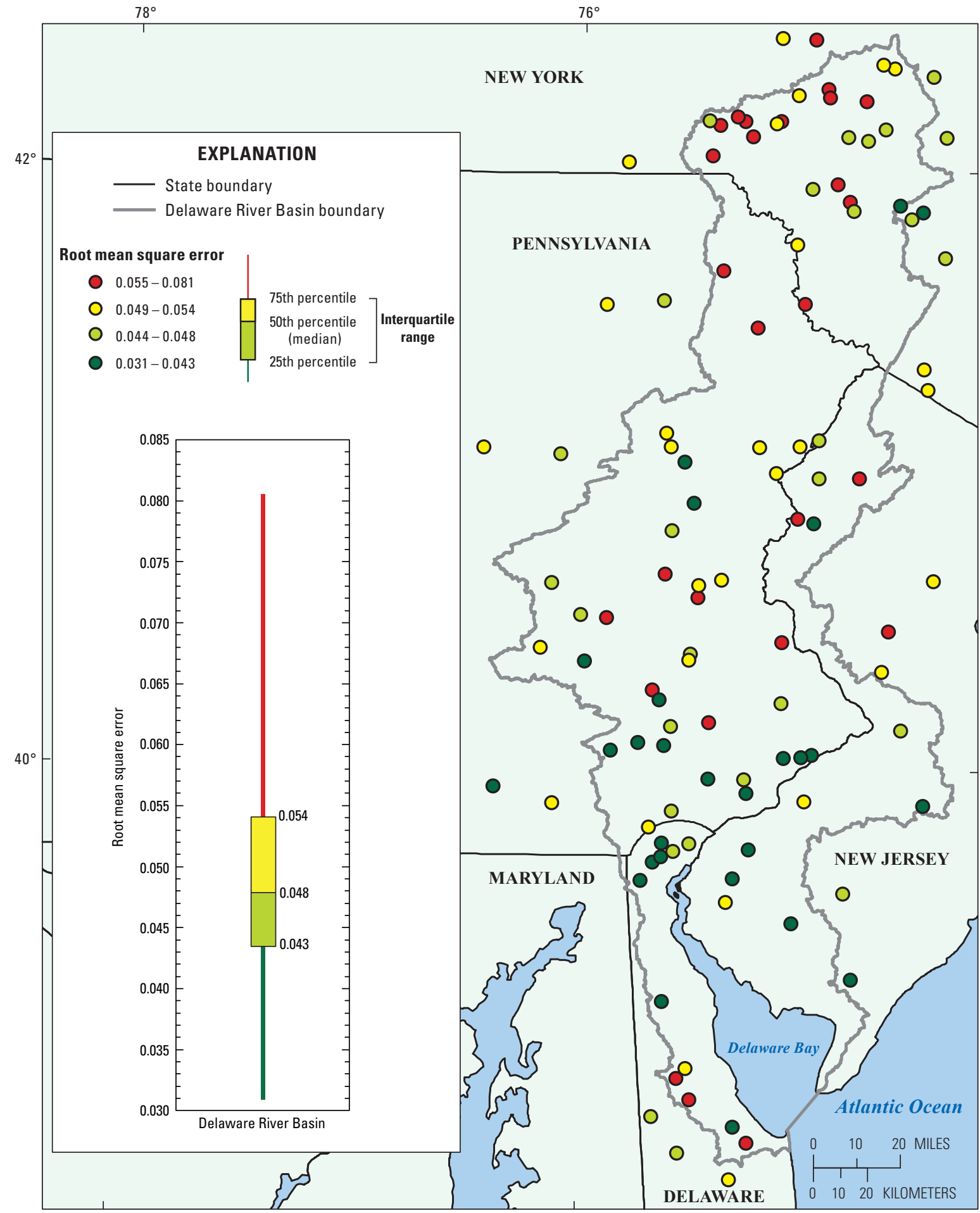

Base modified from U.S. Geological Survey 1:100,000-scale and 1:250,000-scale digital data

Figure 7. Distribution of root mean square error between the observed and estimated streamflow correlations, resulting from map correlation, for 109 streamgages in and near the Delaware River Basin. 


\section{Estimation of Altered Daily Mean Streamflow}

Streamflow is a source of drinking water supply for more than 15 million people in the Delaware River Basin. Other water uses also affect the amount of water flowing in the streams in the basin on any given day. Estimated baseline daily mean streamflow generated using the QPPQ method for the Delaware River Basin was adjusted using compiled water use information to reflect current, or altered, conditions. Withdrawals were compiled and reviewed for accuracy by water use category as part of the National Water Census (Susan Hutson, U.S. Geological Survey, oral commun., 2013). The categories of withdrawals are water supply, self-supplied domestic, industrial, irrigation, livestock, mining, power/ hydroelectric, remediation, sewage treatment, aquaculture, commercial, and thermoelectric. More information on the types of water use categories is presented in Hutson and others, in press. Return flows were not categorized by sector because of insufficient information. The water use data were compiled for all states within the Delaware River Basin for 2010. In addition, water use data were compiled for each year from 2005 through 2010 for the parts of the Delaware River Basin within Pennsylvania and New Jersey. Estimated daily mean streamflows were adjusted to incorporate water use using average withdrawals and returns, by month rather than annually, to capture seasonal and monthly variation in water use.

\section{Use of DRB-SET for Estimating Baseline and Altered Daily Mean Streamflow at Ungaged Stream Locations}

DRB-SET is a tool for simulating streamflow at a daily time step for an ungaged stream location in the Delaware River Basin for WY 1960-2010. DRB-SET is a user friendly and time saving tool used to assist water-resource managers in determining water allocation, ecological flow, and water for human-health needs. DRB-SET is modeled after the BaSE (Stuckey and others, 2014) and MASYE (Archfield and others, 2010) and is written as a stand-alone application on a visual basic.net (VB.NET) platform with the use of Microsoft Excel $^{\circledR}$. Output from the program consists of basin characteristic information, reference streamgage information, baseline and altered daily mean streamflow, mean and median streamflow statistics, FDCs, and hydrographs.

Within DRB-SET the user can utilize an interactive map to select a location of interest (the ungaged stream location). Basin characteristic information for the ungaged stream location can be obtained from the interactive map through StreamStats Web services (Ries and others, 2008) or entered manually. By default, DRB-SET selects an appropriate reference streamgage for a user-entered ungaged stream location by maximizing the estimated streamflow correlation (map correlation). The user has the option of manually selecting a different reference streamgage or using the closest reference streamgage to the ungaged stream location. After the initial information is entered into DRB-SET, the Compute Daily Streamflows function computes the baseline and altered (based on water use in the basin, if applicable) daily mean streamflows for the ungaged stream location for WY 1960-2010. Any altered streamflow incorporates compiled upstream water use into the baseline daily streamflow for the basin by subtracting any withdrawals and adding any return flows.

A report output file, in the form of a Microsoft Excel ${ }^{\circledR}$ spreadsheet, is generated and summarizes the reference streamgage and ungaged stream location information, including basin characteristics and percent difference in basin characteristics between the two locations (fig. 8). Mean and median statistics are computed for the ungaged stream location. FDCs and hydrographs are presented for the ungaged stream location in cubic feet per second $\left(\mathrm{ft}^{3} / \mathrm{s}\right)$ and cubic feet per second per square mile $\left[\left(\mathrm{ft}^{3} / \mathrm{s}\right) / \mathrm{mi}^{2}\right]$. The water use within the basin (if any) is summarized by category in the Water Use report. The estimated daily flows for the ungaged stream location, both baseline and altered, can be easily exported to a text file that can be used as input into a statistical software package to determine additional streamflow statistics, such as low-flow frequencies or monthly flow-duration exceedance probabilities. More information and detailed instructions on the use of DRB-SET can be found in Stuckey and Ulrich, in press.

\section{Accuracy and Limitations of Estimated Streamflow}

Accuracy of estimated daily streamflows for ungaged stream locations is dependent on the uncertainties associated with the multiple steps that compose the overall process. Stuckey and others (2014) outlined the following steps: measurement of streamflow at reference streamgages, streamflow record extension at reference streamgages, estimation of the streamflow for an ungaged stream location on the basis of regression equations, the use of basin characteristics outside the range used to develop the equations, selection of a reference streamgage using the map correlation method, and transfer of exceedance probabilities from the reference streamgage to the ungaged stream location.

The accuracy of measured streamflow data depends on several factors, including the stability of the stage-discharge relation, accuracy of measurements of discharge, and interpretation of streamflow records. Records are rated as excellent, good, fair, or poor. These ratings specify that 95 percent of the daily discharges are within 5 percent (excellent), 10 percent (good), or 15 percent (fair) of their true values. The accuracy of measured streamflow data is documented for each reference 


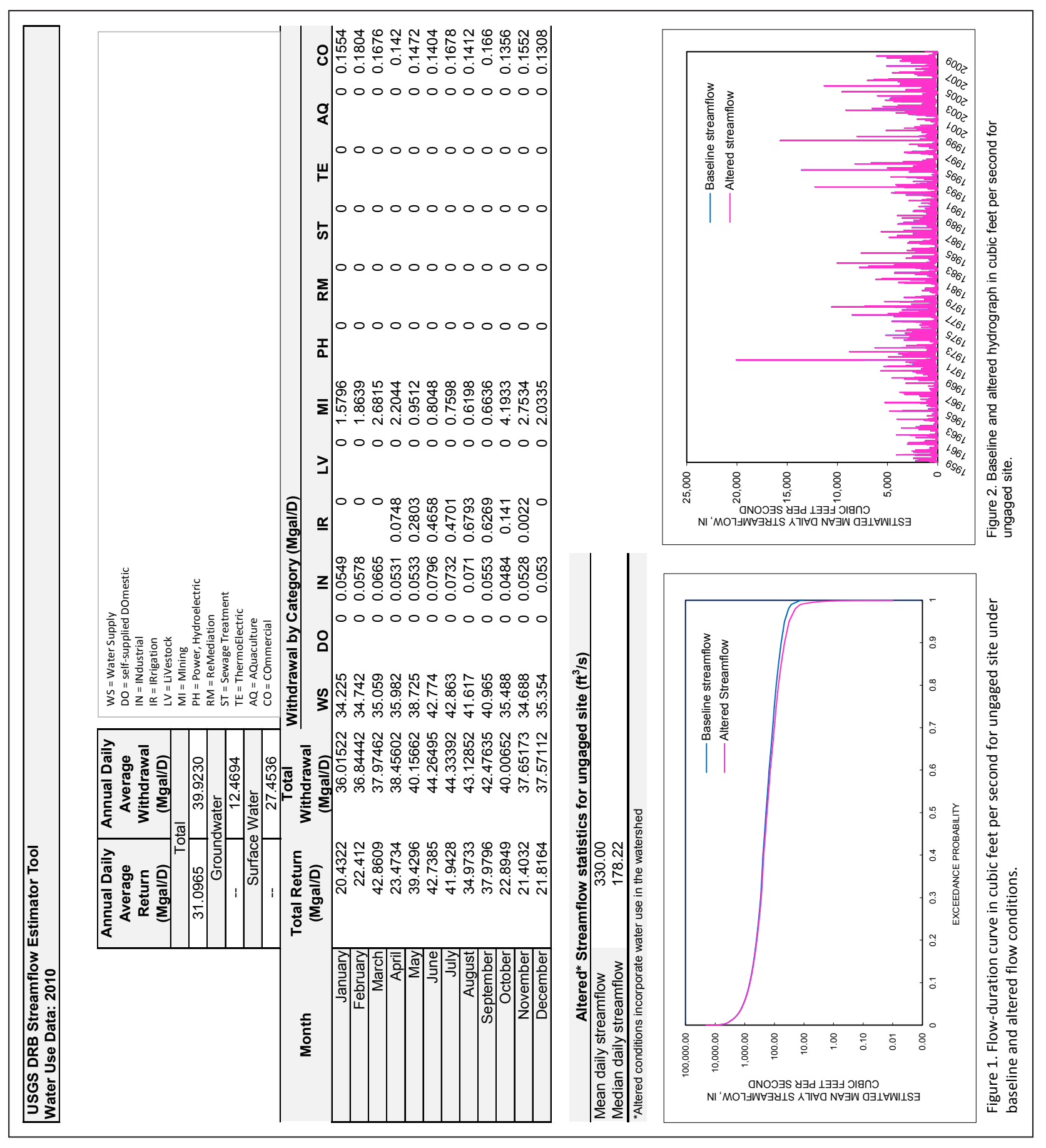

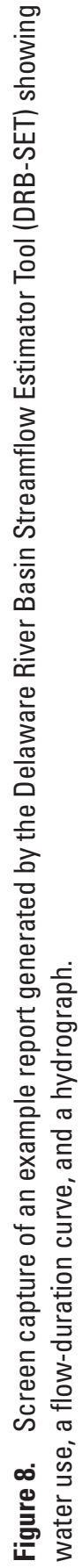


streamgage in annual data reports (http://wdr.water.usgs.gov/) through WY2013. Most of the published streamflow records for the Delaware River Basin are rated good to fair.

Streamflow record extension introduces uncertainty to baseline streamflow estimates, which is difficult to quantify. Because the length of record requiring extension varied by streamgage ( 0 to 82 percent of the record), the uncertainty introduced into the overall record also varies. A general sense of the accuracy of these streamflow estimates can be obtained by observing the correlation coefficients. A maximum correlation of 1.0 indicates a perfect linear relation. In this study, correlation coefficients range from 0.742 to 0.988 . The correlation coefficients are included in Appendix 1. Factoring in the part of the record that required no extension will decrease the overall uncertainty. When the relation between the logarithm of streamflow at a streamgage requiring record extension and the logarithm of streamflow at the reference streamgage is non-linear, the correlations are likely to decrease, and the associated uncertainties are likely to increase. Thus, the overall uncertainty introduced by record extension is a combination of the length of extension period, strength of reference streamgage correlation, and quality of the relation between daily streamflow and daily exceedance probabilities when streamflow is used as a surrogate for exceedance probability.

Uncertainties in the constructed FDC for the ungaged stream locations consist of errors in the regression estimates of the streamflows at the 22 specified exceedance probabilities and uncertainties introduced through interpolation of the remaining unspecified exceedance probabilities of the FDC. Prediction errors for the regression estimates range from 11 to 79 percent. The median and mean predictive errors are 24 and
32 percent, respectively. All other exceedance probabilities that are not predicted from regression equations are log-log interpolated.

DRB-SET relies on estimates of streamflow derived from regression equations and is not meant to be used for streams with basin characteristics outside the range used to develop the equations. Estimates of streamflow for streams with basin characteristics outside this range may not be valid. The range of basin characteristics used in the development of the regression equations is shown in table 4 . The maximum percent impervious for watersheds to be used in DRB-SET generally should be less than 10 percent. For watersheds with percent imperviousness greater than this value, results from DRB-SET need to be evaluated very carefully before use. If groundwater and surface-water divides are not coincident, which can occur in areas with karst topography or mining, results from the regression equations and DRB-SET also may not be valid.

The selection of a reference streamgage by map correlation affects the uncertainty in the streamflow estimates by way of the accuracy with which the best correlated reference streamgage is selected. Even when the best correlated reference streamgage is selected by map correlation, uncertainty is introduced into the daily exceedance probabilities for the ungaged stream location because the reference streamgage would still not be perfectly correlated. Additional uncertainty would be introduced if map correlation did not select the best correlated reference streamgage. A comparison between streamflow estimates resulting from DRB-SET using map correlation and the closest streamgage method to select a reference streamgage was performed using NSE with the logs (base10) of the streamflow. A perfect match of modeled to the

Table 4. Range of basin characteristics used in the development of regression equations to estimate flow-duration exceedance probability discharges for ungaged stream locations within the Delaware River Basin.

\begin{tabular}{lllll}
\hline \multicolumn{1}{c}{ Basin characteristic } & Mean & Median & Minimum & Maximum \\
\hline $\begin{array}{l}\text { Latitude at outlet } \\
\text { (decimal degrees) }\end{array}$ & 40.760392 & 40.636665 & 38.638861 & 42.450968 \\
\hline $\begin{array}{l}\text { Drainage area } \\
\quad \text { (square miles) }\end{array}$ & 81.2 & 45.7 & 0.61 & 1,147 \\
$\begin{array}{l}\text { Mean annual precipitation } \\
\quad \text { (inches) }\end{array}$ & 47.3 & 46.6 & 42.6 & 59.2 \\
\hline $\begin{array}{l}\text { Mean winter precipitation } \\
\quad \text { (inches) }\end{array}$ & 3.28 & 3.30 & 2.69 & 4.29 \\
$\begin{array}{l}\text { Poorly drained soil } \\
\text { (percent) }\end{array}$ & 7.06 & 4.26 & 0.00 & 47.8 \\
\hline $\begin{array}{l}\text { Sand in soil (percent) } \\
\text { Saturated hydraulic conductivity } \\
\text { (micrometers/second) }\end{array}$ & 42.1 & 38.4 & 17.6 & 86.5 \\
\hline
\end{tabular}


observed data would result in a NSE value of 1.0. The results are shown in figure 9 . Both methods for selecting a reference streamgage produce streamflow estimates in good agreement with the observed streamflow; however, those resulting from map correlation perform slightly better, as indicated by more points falling below the line of equal NSE (fig. 9). Those points that fall on the line of equal NSE represent instances where both methods for selecting the best streamgage selected the same reference streamgage.

The median NSE values resulting from the use of map correlation and the closest gage are 0.85 and 0.83 , respectively. The greatest discrepancy between the two methods is shown by streamgage 01426000 , Oquaga Creek at Deposit, N.Y., with a drainage area $67.6 \mathrm{mi}^{2}$. The use of map correlation resulted in the selection of 01425675, Oquaga Creek near North Sanford, N.Y. (drainage area $4.69 \mathrm{mi}^{2}$ ) as the most representative reference streamgage with a NSE value of 0.87 ; the use of the closest gage resulted in the selection of 01425500 , Cold Spring Brook at China, N.Y. (drainage area $1.50 \mathrm{mi}^{2}$ ) as the most representative reference streamgage with a NSE value of -0.27 . In this example, the closest gage (01425500) is in a neighboring watershed, whereas the streamgage with the highest estimated correlation (01425675) is in the headwaters of the same watershed. Both streamgages are well outside the range of suggested drainage area ratios (Roland and Stuckey, 2008), however, the other basin characteristics for 01426000 and 01425675 are similar whereas some of the basin characteristics differ between 01426000 and 01425500 (Appendix 2). This difference in basin characteristics, especially percent of poorly drained soil, likely contributed to the lower NSE value seen with the use of the closest gage.

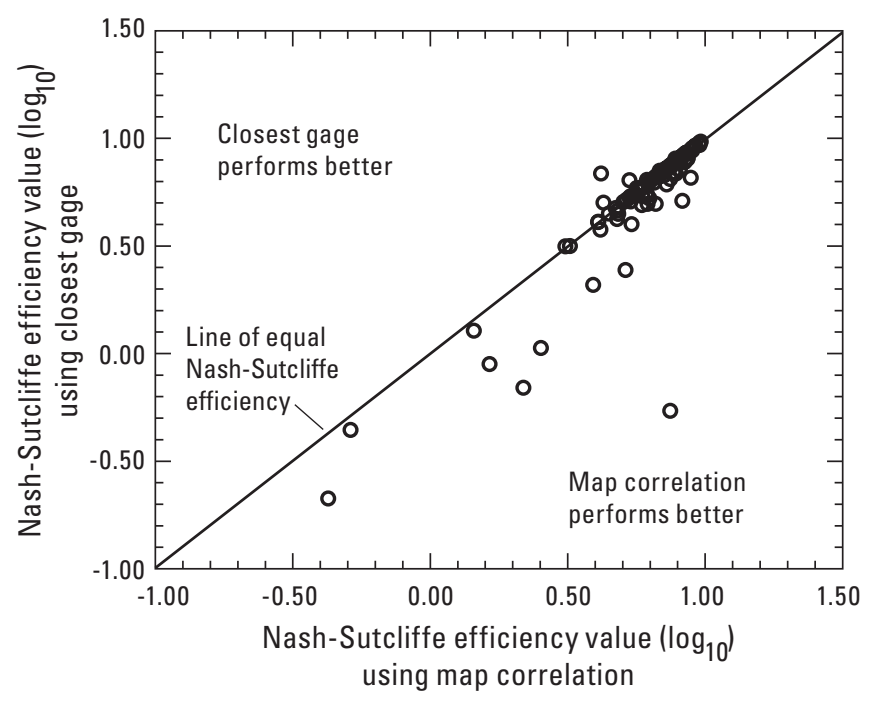

Figure 9. Nash-Sutcliffe efficiency values determined using the closest streamgage and map correlation in the Delaware River Basin Streamflow Estimator Tool.
The transfer of streamflow exceedance probabilities from a reference streamgage to an ungaged stream location using the QPPQ method relies on the assumption that both locations experience identical exceedance probabilities at identical times. Isolated storm events frequently occur that affect one subbasin but not other nearby subbasins. This is especially true when the ungaged subbasin has a much smaller or larger drainage area than the reference streamgage subbasin.

To evaluate how well DRB-SET estimates daily mean streamflow, a comparison of observed and estimated daily mean streamflows was performed for all the reference streamgages within the Delaware River Basin. The reference streamgages were run through DRB-SET as ungaged stream locations, and the estimated streamflow was compared to the observed using NSE $\left(\log _{10}\right)$ values as a measure of goodness of fit. Reference streamgages were selected using the default map correlation method. NSE $\left(\log _{10}\right)$ values ranged from 0.22 to 0.98 (median of 0.90) for the Upper Delaware River Basin and from -0.37 to 0.98 (median of 0.79 ) for the Lower Delaware River Basin (table 5 and fig. 10). The lowest NSE value (-0.37) is from 01466500, McDonalds Branch in Byrne State Forest, N.J., with a drainage area of $2.34 \mathrm{mi}^{2}$; the percent sand in soil is 86.5 percent, which is the maximum used in the overall analysis. The spatial distribution of the NSE values determined for each reference streamgage within the Delaware River Basin is shown in figure 11. Two of the three remaining reference streamgages with NSE values less than or equal to zero are located to the west of the Delaware Bay in Delaware and have small drainage areas (fig. 11). The final reference streamgage with an NSE value less than or equal to zero is located in the western part of the basin on the Tulpehocken Creek (fig. 11).

Hydrographs and FDCs generated from DRB-SET for streamgages 01420500, Beaver Kill at Cooks Falls, N.Y., and 01464500, Crosswicks Creek at Extonville, N.J., are shown in figures $12 A$ and $12 B$, respectively. Streamgage 01420500 was associated with reference streamgage 01418500 with an estimated streamflow correlation (using map correlation) of 0.99 , and streamgage 01464500 was associated with reference streamgage 01401000 with an estimated streamflow correlation (using map correlation) of 0.86 for estimates of daily mean flow. While both of these estimated streamflow correlations are fairly high, they represent the best (01420500) and worst (01464500) estimated streamflow correlations for reference streamgages with measured streamflow for WY 19602010. The low-flow period from WY 1998 to 2002 is shown in the hydrographs in figure 12. Although both hydrographs show good general fit between the estimated and observed streamflows, the hydrograph for 01464500 shows more variance, which is reflected in the lower NSE $\left(\log _{10}\right)$ value of 0.59 in comparison to the NSE $\left(\log _{10}\right)$ value of 0.98 associated with 01420500 . 
Table 5. Nash-Sutcliffe efficiency values between observed and estimated daily mean streamflows in the Delaware River Basin.

\begin{tabular}{lccccc}
\hline \multicolumn{1}{c}{ Location } & $\begin{array}{c}\text { Number of } \\
\text { streamgages }\end{array}$ & $\begin{array}{c}\text { Minimum Nash- } \\
\text { Sutcliffe } \\
\text { efficiency value } \\
\left(\log _{10}\right)\end{array}$ & $\begin{array}{c}\text { Maximum Nash- } \\
\text { Sutcliffe } \\
\text { efficiency value } \\
\left(\log _{10}\right)\end{array}$ & $\begin{array}{c}\text { Mean Nash- } \\
\text { Sutcliffe } \\
\text { efficiency value } \\
\left(\log _{10}\right)\end{array}$ & $\begin{array}{c}\text { Median Nash- } \\
\text { Sutcliffe } \\
\text { efficiency value } \\
\left(\log _{10}\right)\end{array}$ \\
\hline Upper Delaware River Basin & 45 & 0.22 & 0.98 & 0.86 & 0.90 \\
Lower Delaware River Basin & 41 & -0.37 & 0.98 & 0.72 & 0.79 \\
Entire Delaware River Basin & 86 & -0.37 & 0.98 & 0.78 & 0.80 \\
Outside Delaware River Basin & 24 & 0.49 & 0.96 & 0.83 \\
\hline
\end{tabular}

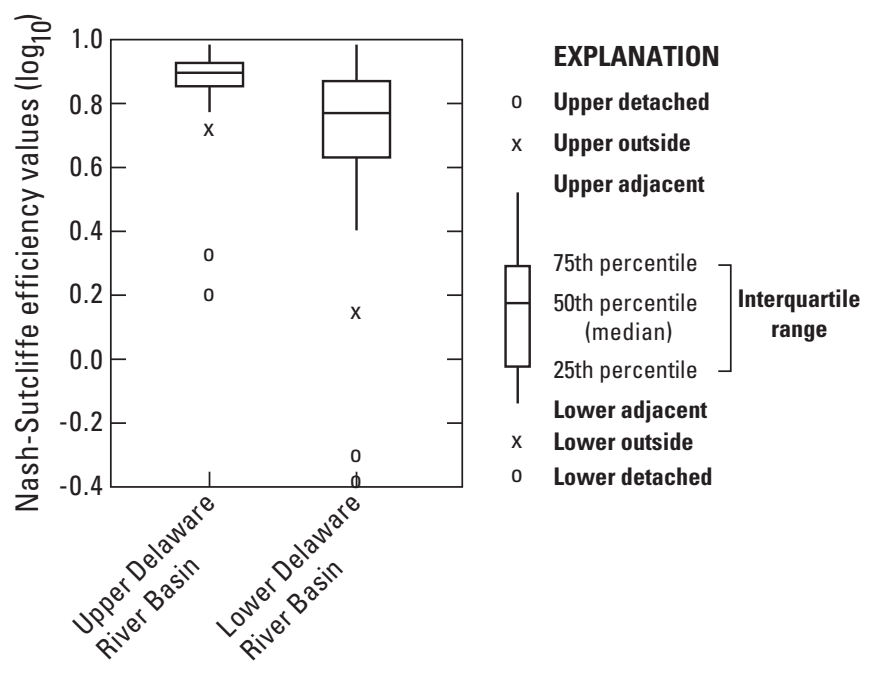

Figure 10. Distribution of Nash-Sutcliffe efficiency values between observed and estimated daily mean streamflows in the Upper and Lower Delaware River Basin. 


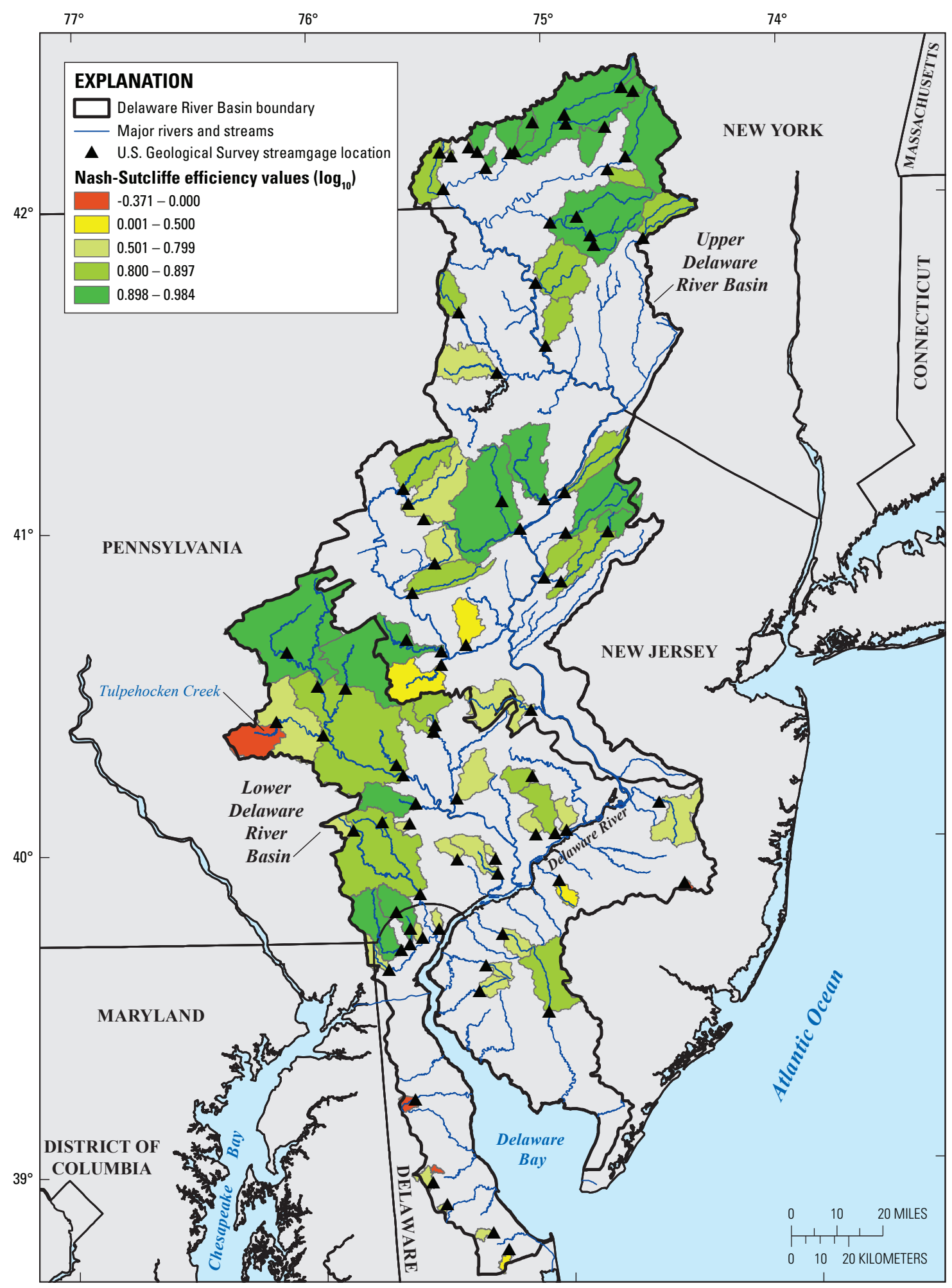

Base modified from U.S. Geological Survey 1:100,000-scale and 1:250,000-scale digital data

Figure 11. Spatial distribution of Nash-Sutcliffe efficiency values for reference streamgage basins in the Delaware River Basin. 

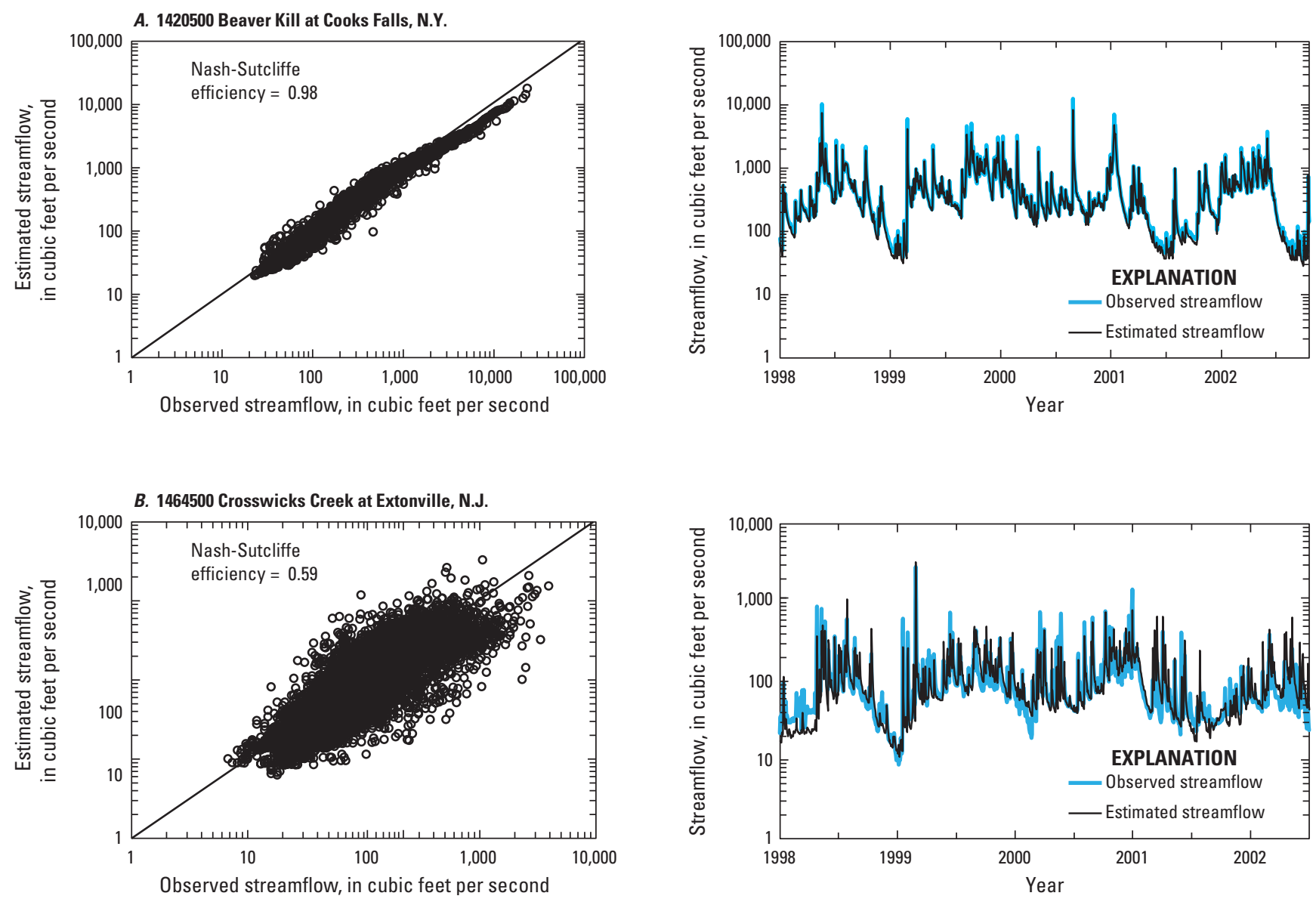

Figure 12. Estimated and observed daily mean streamflows for U.S. Geological Survey streamgages $A, 01420500$, Beaver Kill at Cooks Falls, New York, water years 1999-2002, and B, 01464500, Crosswicks Creek at Extonville, New Jersey, water years $1999-2002$. 


\section{Summary}

The Delaware River Basin encompasses more than 13,500 square miles in parts of four states - New York, New Jersey, Pennsylvania, and Delaware - and has a population of approximately 8.3 million. In the upper parts of the basin, concerns over the effects of new natural gas development and the freshwater requirements for a recently discovered endangered mussel species have added new complexities to water management in the basin. Hydrologic and ecological data can be directly related to provide the basis for understanding the flow needs of aquatic species found in the tributaries of the Delaware River Basin. Providing the data and tools to understand and define flow-alteration ecological-response relations will assist water-resource managers and policy makers in meeting the ecological flow needs of aquatic species in the Delaware River Basin.

The U.S. Geological Survey, through the National Water Census, has developed a tool to estimate streamflow at a daily time step for ungaged stream locations in the Delaware River Basin. The Delaware River Basin Streamflow Estimator Tool (DRB-SET) is a tool for simulating streamflow at a daily time step for an ungaged stream location in the Delaware River Basin for water years (WY) 1960-2010. Daily mean streamflow is estimated using the QPPQ method, which equates streamflow expressed as a percentile from the flow-duration curve (FDC) for a particular day at an ungaged stream location with the percentile from a FDC for the same day at a hydrologically similar location where streamflow is observed. Parameter-based regression equations were developed for 22 exceedance probabilities from the FDC for ungaged stream locations in the Delaware River Basin. Prediction errors for the 22 regression estimates ranged from 11 to 79 percent. Streamflow data from continuous-record streamgages were used to develop correlation maps of the predicted correlation of streamflow between an ungaged stream location and a reference streamgage. Water use data from 2010 were used to adjust the baseline daily mean streamflow generated from the QPPQ method at ungaged stream locations in the Delaware River Basin to reflect non-baseline conditions which may be affected by anthropogenic water usage.

To evaluate the effectiveness of the overall QPPQ method contained within DRB-SET, a comparison of observed and estimated daily mean streamflows was performed for 109 reference streamgages in and near the Delaware River Basin. The Nash-Sutcliffe efficiency (NSE) values were computed as a measure of goodness of fit; a maximum value of 1.0 would indicate a perfect match of modeled and observed data. The NSE values (using $\log _{10}$ streamflow values) ranged from 0.22 to 0.98 (median of 0.90) for the Upper Delaware River Basin and from -0.37 to 0.98 (median of 0.79 ) for the Lower Delaware River Basin.
The accuracy of estimated daily streamflows for ungaged stream locations is dependent on the uncertainties associated with the multiple steps that compose the overall process. These steps include measurement of streamflow at reference streamgages, streamflow record extension at reference streamgages, estimation of the FDC for an ungaged stream location on the basis of regression equations and basin characteristics, selection of a reference streamgage using the map correlation method, and transfer of exceedance probabilities from reference streamgage to the ungaged stream location.

\section{Acknowledgments}

The author thanks Martyn Smith of the U.S. Geological Survey (USGS) for providing assistance with the geographic information systems and StreamStats that was necessary for the completion of the project. The author also thanks Stacey Archfield, USGS, for her assistance in running the map correlations and her expertise in the QPPQ process. Other USGS colleagues also made substantive contributions: Jeffrey Fischer provided helpful feedback pertaining to the overall National Water Census and technical reviews were provided by Thomas Over and Mark Roland.

\section{References Cited}

Alley, W.M., Evenson, E.J., Barber, N.L., Bruce, B.W., Dennehy, K.F., Freeman, M.C., Freeman, W.O., Fischer, J.M., Hughes, W.B., Kennen, J.G., Kiang, J.E., Maloney, K.O., Musgrove, MaryLynn, Ralston, Barbara, Tessler, Steven, and Verdin J.P., 2013, Progress toward establishing a national assessment of water availability and use: U.S. Geological Survey Circular 1384, 34 p. [Also available at http://pubs.usgs.gov/circ/1384.]

Archfield, S.A., Steeves, P.A., Guthrie, J.D., and Ries III, K.G., 2012, A web-based software tool to estimate unaltered daily streamflow at ungauged rivers, Geoscience Model Development. Discussions, no. 5, p. 2,503-2,526, DOI:10.5194/gmdd-5-2503-2012, 2012.

Archfield, S.A., and Vogel, R.M., 2010, Map correlation method: Selection of a reference streamgage to estimate daily streamflow at ungaged catchments: Water Resources Research, no. 46, no. 10, W10513, DOI:10.1029/2009WR008481. 
Archfield, S.A., Vogel, R.M., Steeves, P.A., Brandt, S.L., Weiskel, P.K., and Garabedian, S.P., 2010, The Massachusetts Sustainable-Yield Estimator: A decision-support tool to assess water availability at ungaged stream locations in Massachusetts: U.S. Geological Survey Scientific Investigations Report 2009-5227, 41 p., plus CD-ROM, http://pubs.usgs.gov/sir/2009/5227/.

Daly, C., Neilson, R.P., and Phillips, D.L., 1994, A statisticaltopographic model for mapping climatological precipitation over mountainous terrain: Journal of Applied Meteorology, v. 33, no. 2, p. 140-158, DOI: http://dx.doi. org/10.1175/1520-0450(1994)033\%3C0140:ASTMFM\%3E 2.0.CO;2.

Delaware River Basin Commission, 2013, Delaware River Basin Commission Annual Report, 28 p., http://www. nj.gov/drbc/library/documents/2013AR.pdf.

Fennessey, N.M., 1994, A hydro-climatological model of daily streamflow for the northeast United States: Medford, Mass., Tufts University, Ph.D. dissertation [variously paged].

Fischer, J.M., Riva-Murray, Karen, Hickman, R.E., Chichester, D.C., Brightbill, R.A., Romanok, K.M., and Bilger, M.D., 2004, Water quality in the Delaware River Basin, Pennsylvania, New Jersey, New York, and Delaware, 1998-2001: U.S. Geological Survey Circular 1227, 39 p., http://pubs.usgs.gov/circ/2004/1227/pdf/circular1227.pdf.

Fry, J., Xian, G., Jin, S., Dewitz, J., Homer, C., Yang, L., Barnes, C., Herold, N., and Wickham, J., 2011, Completion of the 2006 National Land Cover Database for the Conterminous United States: Photogrammetric Engineering and Remote Sensing, v. 77, no. 9, p. 858-864, http://www. mrlc.gov/nlcd2006.php.

Gazoorian, C.L., 2015, Estimation of unaltered daily mean streamflow at ungaged streams of New York, excluding Long Island, water years 1961-2010: U.S. Geological Survey Scientific Investigations Report 2014-5220, 29 p., http://dx.doi.org/10.3133/sir20145220.

Gesch, Dean, Oimoen, Michael, Greenlee, Susan, Nelson, Charles, Steuck, Michael, and Tyler, Dean, 2002, The National Elevation Dataset: Photogrammetric Engineering and Remote Sensing, v. 68, no. 1, http://www.asprs.org/a/ publications/pers/2002journal/january/highlight.html.

Granato, G.E., 2009, Computer programs for obtaining and analyzing daily mean streamflow data from the U.S. Geological Survey National Water Information System Web Site: U.S. Geological Survey Open-File Report 2008-1362, 123 p. on CD-ROM, 5 appendixes, http://pubs.usgs.gov/ of/2008/1362/.
Helsel, D.R., and Hirsch, R.M., 2002, Statistical methods in water resources: U.S. Geological Survey Techniques of Water-Resources Investigations, book 4, chap. A3, 522 p. [Also available at http://pubs.usgs.gov/twri/twri4a3/.]

Hirsch, R.M., 1982, A comparison of four streamflow record extension techniques: Water Resources Research, v. 18, no. 4, p. 1,081-1,088, DOI: 10.1029/WR018i004p01081.

Hughes, D.A., and Smakhtin, V.Y., 1996, Daily flow time series patching or extension: a spatial interpolation approach based on flow duration curves: Journal of Hydrological Sciences, v. 41, no. 6, p. 851-871, DOI:10.1080/02626669609491555.

Hutson, S.S., Linsey, K.S., Ludlow, R.A., Reyes, Betzaida, and Shourds, J.L., in press, Estimated use of water in the Delaware River Basin in Delaware, New Jersey, New York, Pennsylvania, 2010: U.S. Geological Survey Scientific Investigations Report 2015-5142.

Isaaks, E.H., and Srivastava, R.M., 1989, An introduction to applied geostatistics: New York and Oxford, Oxford University Press, $561 \mathrm{p}$.

Jenner, C.B., and Lins, H.F., 1991, Climatic atlas of the Delaware River Basin: U.S. Geological Survey Professional Paper 1392, 127 p., https://pubs.er.usgs.gov/publication/ pp1392.

Lellis, W.A. 2001, Freshwater Mussel Survey of the Delaware Scenic and Recreational River, Qualitative Survey 2000: Report to the National Park Service, February 20, 2001, 6 p.

Mohamoud, Y.M., 2008, Prediction of daily flow duration curves and streamflow for ungauged catchments using regional flow duration curves: Journal of Hydrological Sciences, v. 53, no. 4, p. 706-724, DOI: 10.1623/ hysj.53.4.706.

Ries, K.G., III, comp., 2007, The national streamflow statistics program: A computer program for estimating streamflow statistics for ungaged sites: U.S. Geological Survey Techniques and Methods 4-A6, 37 p., http://pubs.usgs.gov/ $\mathrm{tm} / 2006 / \mathrm{tm} 4 \mathrm{a} 6 /$.

Ries, K.G., III, Guthrie, J.D., Rea, A.H., Steeves, P.A., and Stewart, D.W., 2008, StreamStats: A water resources web application: U.S. Geological Survey Fact Sheet 2008-3067, 6 p., http://pubs.usgs.gov/fs/2008/3067/.

Roland, M.A., and Stuckey, M.H., 2008, Regression equations for estimating flood flows at selected recurrence intervals for ungaged streams in Pennsylvania: U.S. Geological Survey Scientific Investigations Report 2008-5102, 57 p., http://pubs.usgs.gov/sir/2008/5102/. 
Searcy, J.K., 1960, Graphical correlation of gaging-station records: U.S. Geological Survey Water-Supply Paper 1541C, p. 67-100, http://pubs.usgs.gov/wsp/1541c/report.pdf.

Shu, Chang, and Ourda, T.B.M.J., 2012, Improved methods for daily streamflow estimates at ungauged sites: Water Resources Research, v. 48, W02523, DOI:10.1029/2011WR011501.

Smakhtin, V.Y., 1999, Generation of natural daily flow time series in regulated rivers using a nonlinear spatial interpolation technique: Regulated Rivers Research and Management, v.15, 12 p., DOI:10.1002/(SICI)10991646(199907/08)15:4<311::AID-RRR544>3.0.CO;2-W.

Smakhtin, V.Y. and Masse, B., 2000, Continuous daily hydrograph simulation using duration curves of a precipitation index: Hydrological Processes, v. 14, no. 6, p. 1,083-1,100, DOI: 10.1002/(SICI)10991085(20000430)14:6<1083::AID-HYP998>3.0.CO;2-2.
Soil Survey Staff, Natural Resources Conservation Service, United States Department of Agriculture, Web Soil Survey, accessed December 21, 2015, at http://websoilsurvey.nrcs. usda.gov/.

Stuckey, M.H., Koerkle, E.H., and Ulrich, J.E., 2014, Estimation of baseline daily mean streamflows for ungaged locations on Pennsylvania streams, water years 1960-2008 (ver 1.1, August 2014): U.S. Geological Survey Scientific Investigations Report 2012-5142, 61 p., http://pubs.usgs. gov/sir/2012/5142.

Stuckey, M.H., and Ulrich, J.E., in press, User's Guide for the Delaware River Basin Streamflow Estimator Tool (DRB-SET): U.S. Geological Survey Open-File Report 2015-1192.

TIBCO Software Inc., 2008, TIBCO Spotfire S+ 8.1 Guide to Packages: Palo Alto, Calif., 77 p. 
Appendixes 1-3 


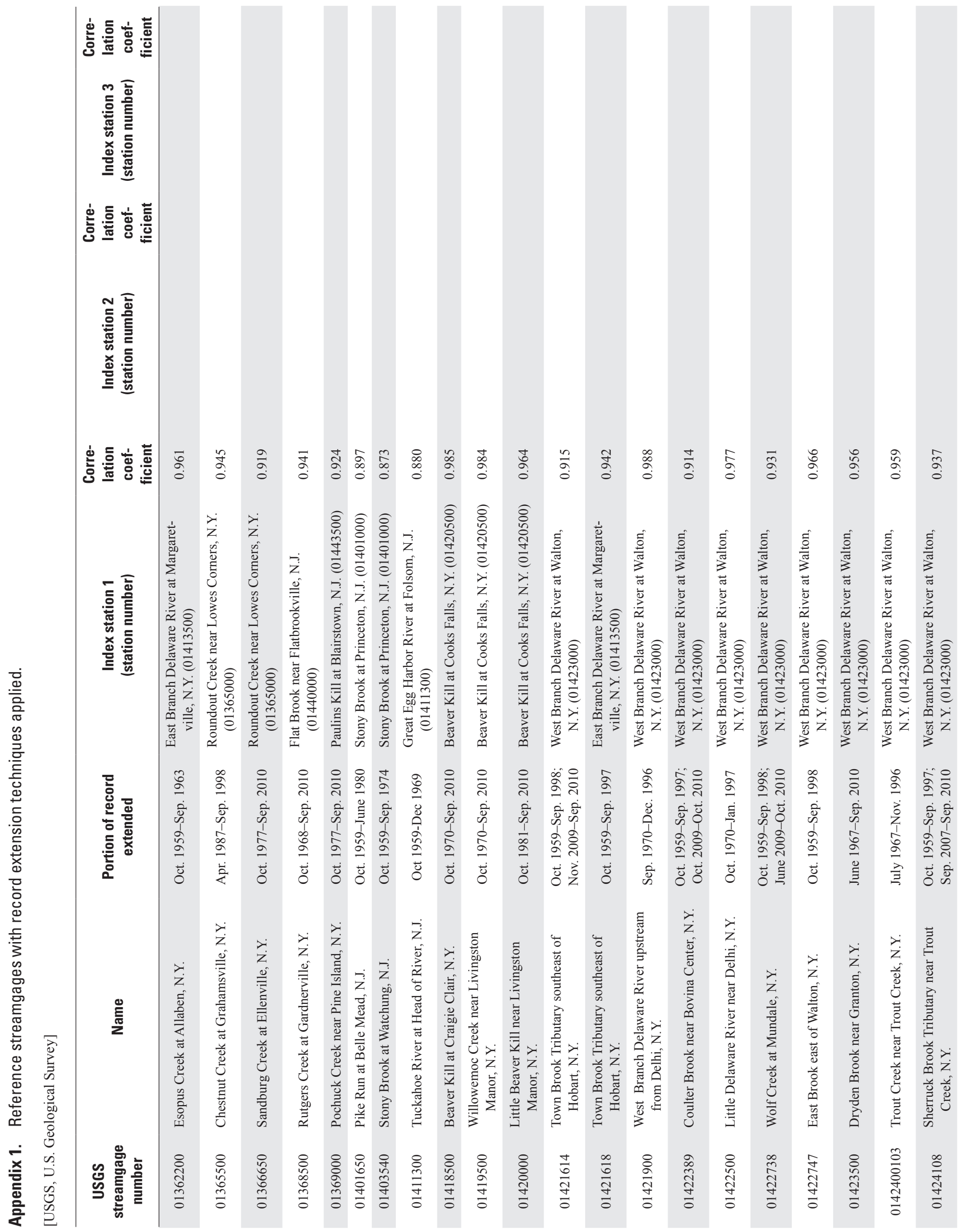




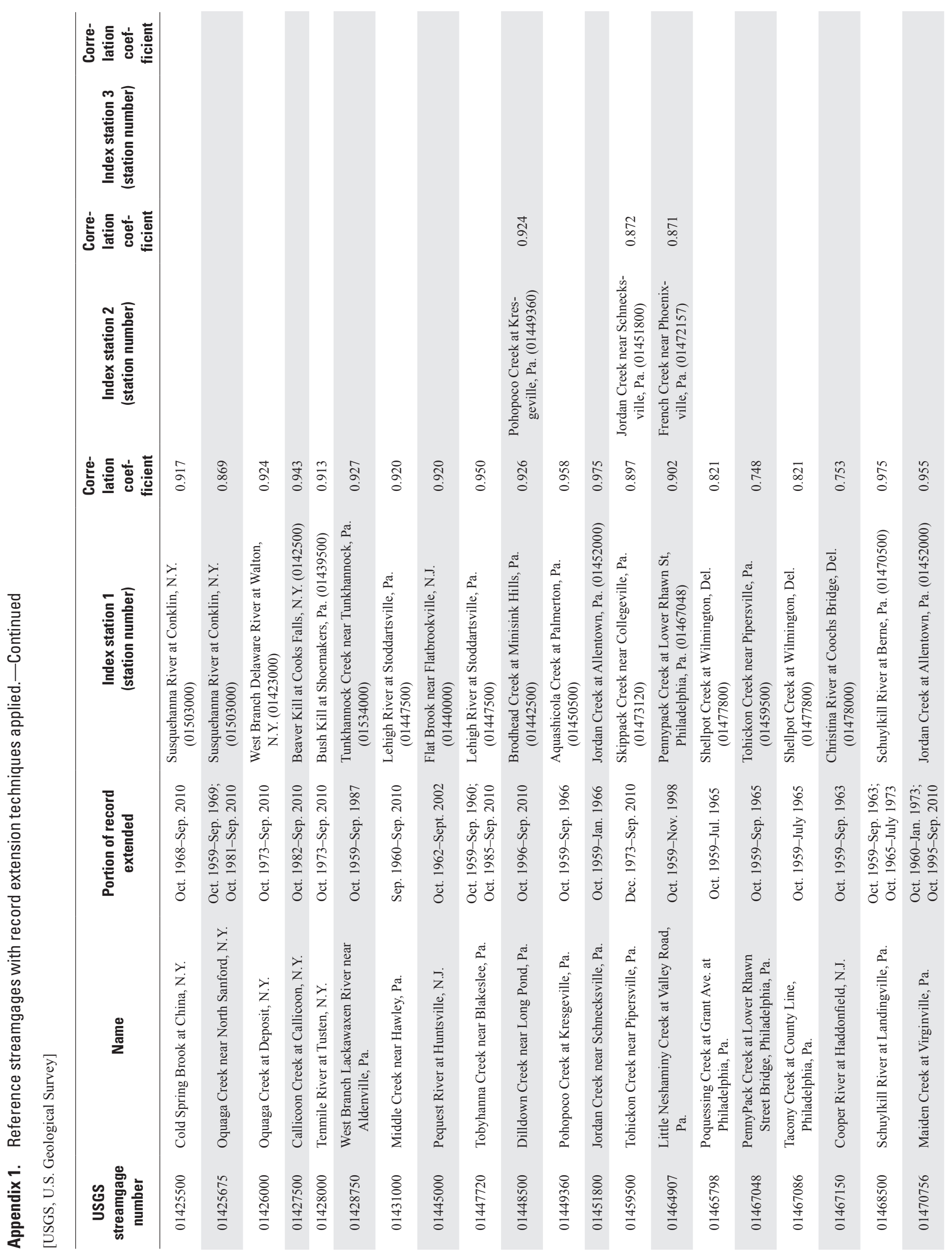




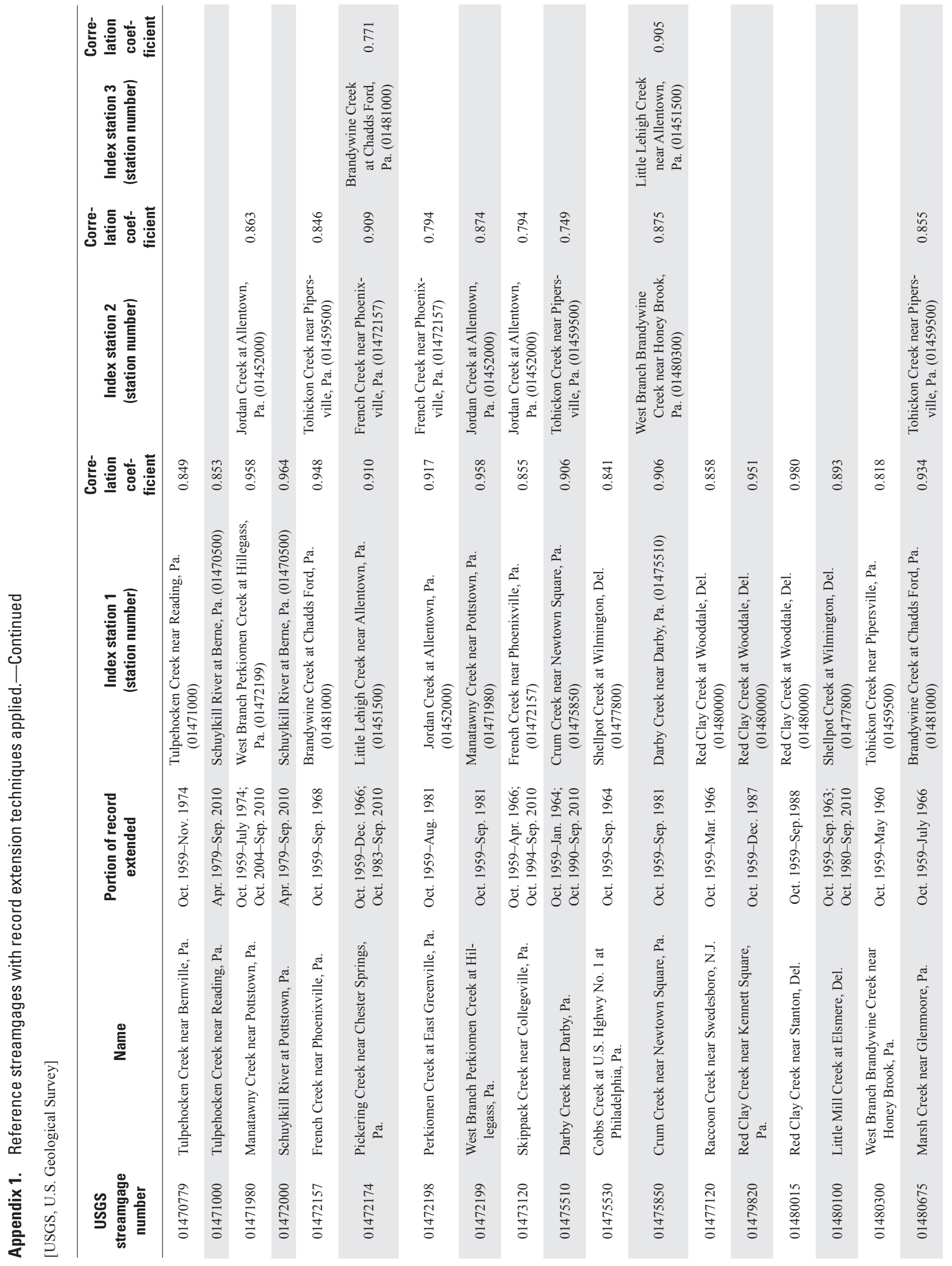




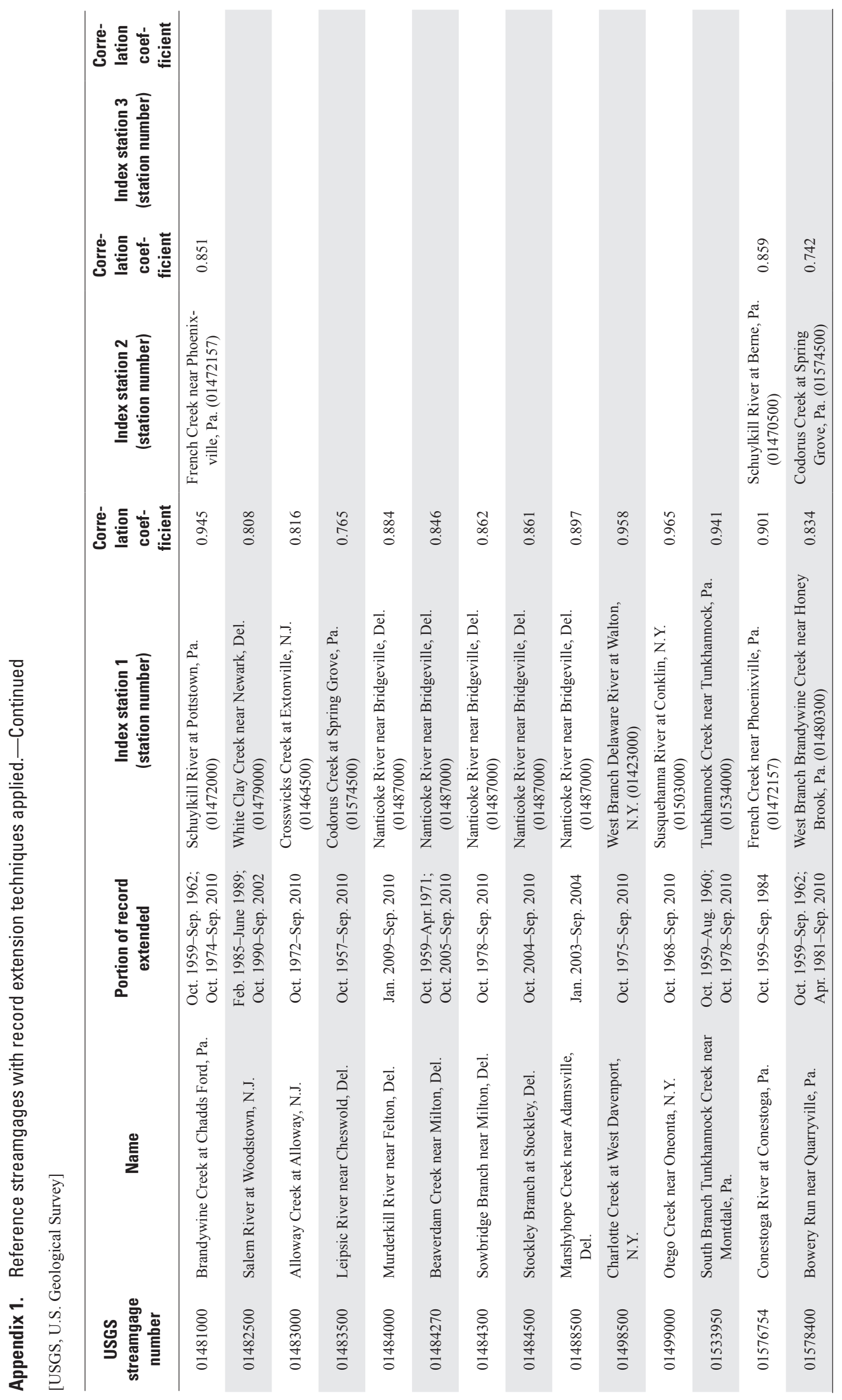


Appendix 2. Basin characteristics used in the development of flow-duration exceedance probability regression equations for the Delaware River Basin.

[USGS, U.S. Geological Survey; mean annual precipitation, 1981-2010; mean winter precipitation, December-February, 1981-2010]

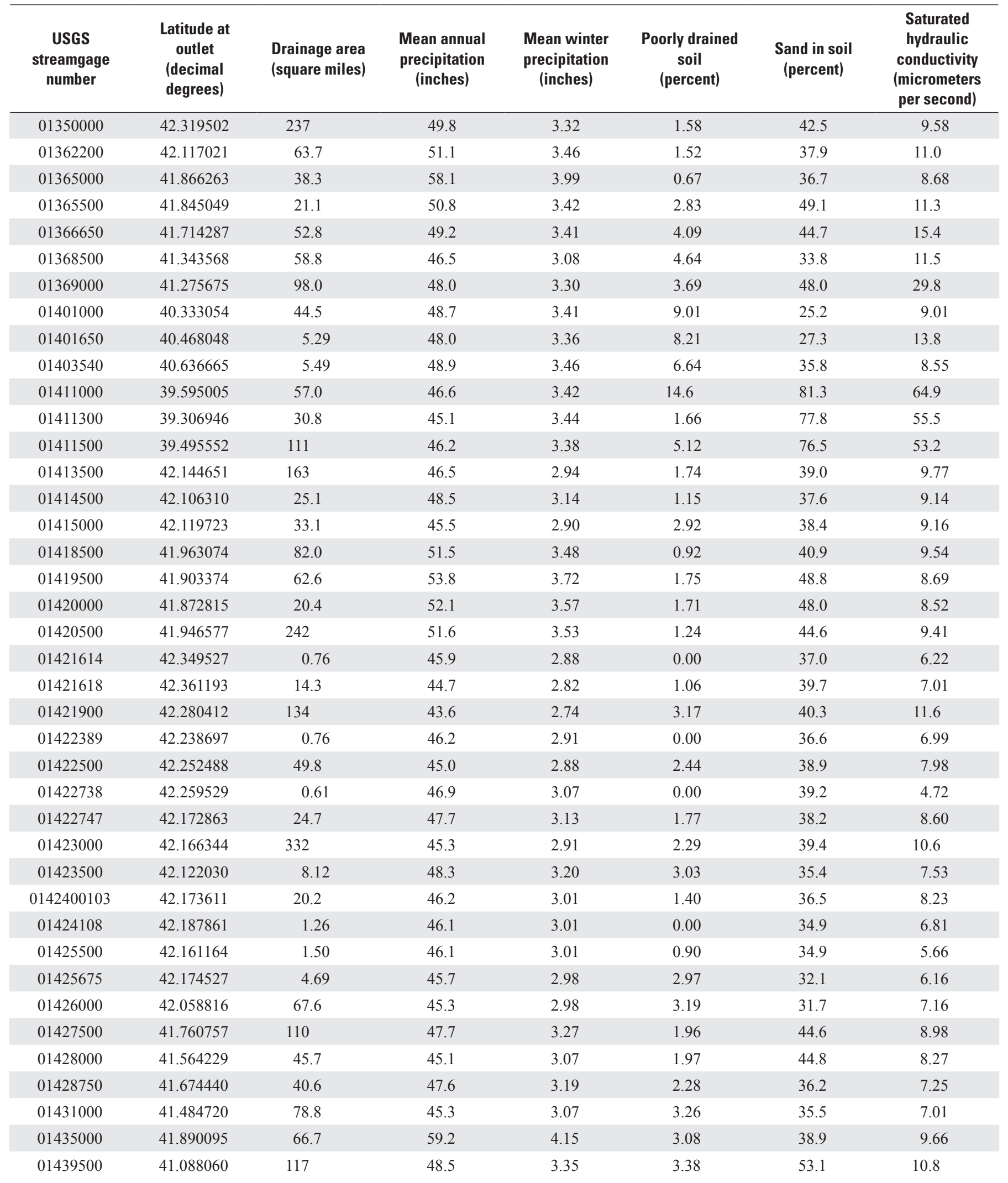


Appendix 2. Basin characteristics used in the development of flow-duration exceedance probability regression equations for the Delaware River Basin.-Continued

[USGS, U.S. Geological Survey; mean annual precipitation, 1981-2010; mean winter precipitation, December-February, 1981-2010]

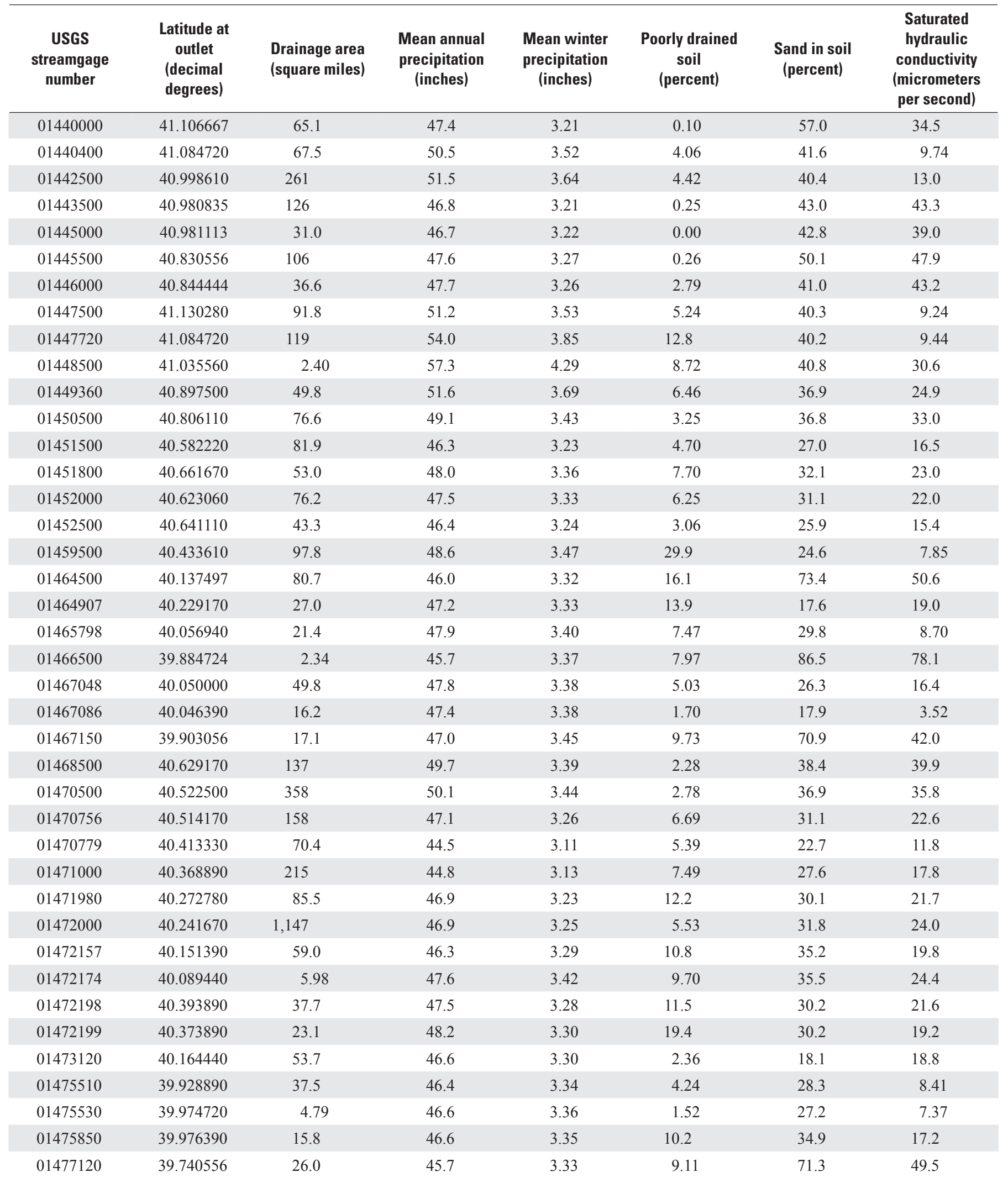


Appendix 2. Basin characteristics used in the development of flow-duration exceedance probability regression equations for the Delaware River Basin.-Continued

[USGS, U.S. Geological Survey; mean annual precipitation, 1981-2010; mean winter precipitation, December-February, 1981-2010]

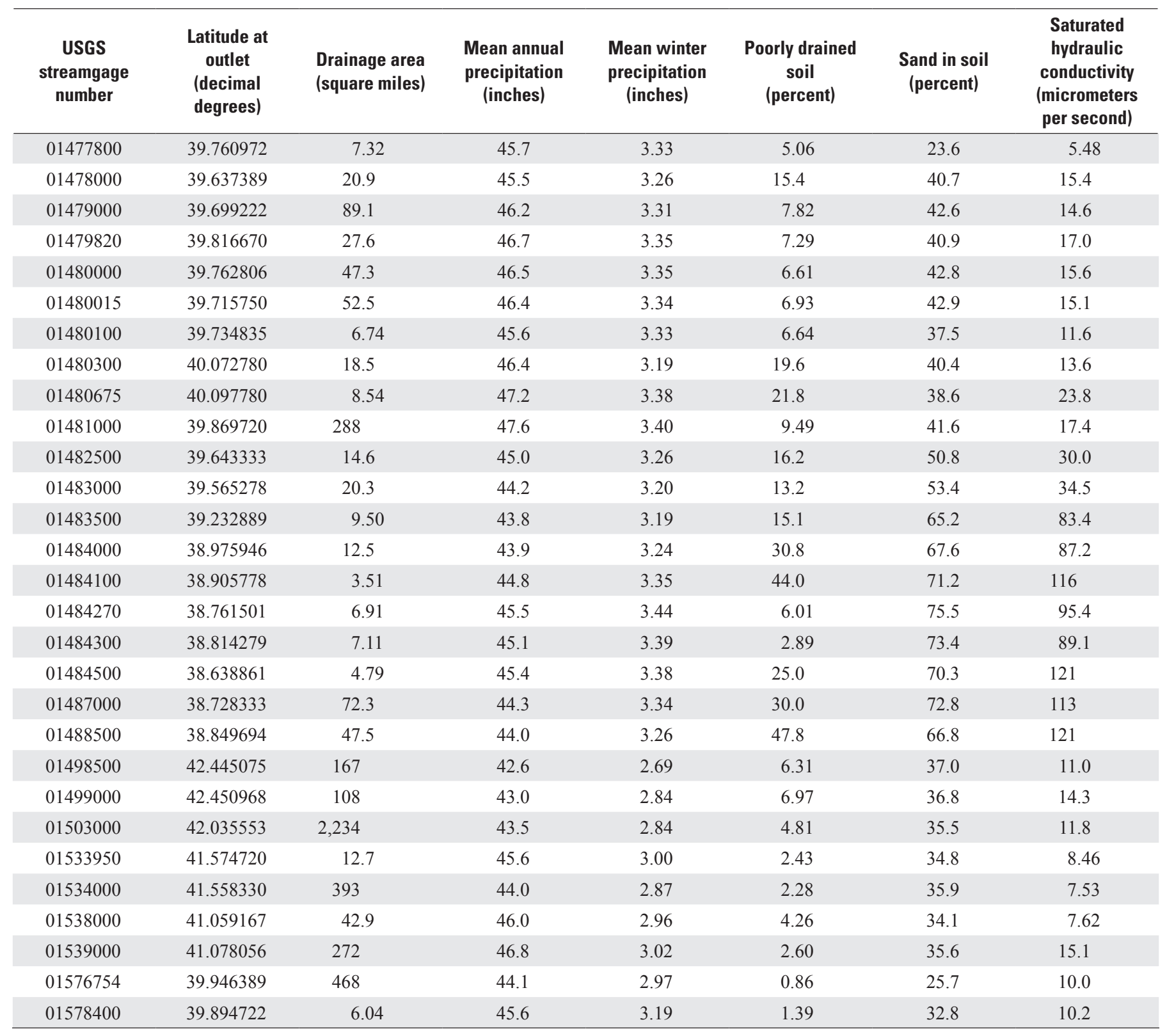




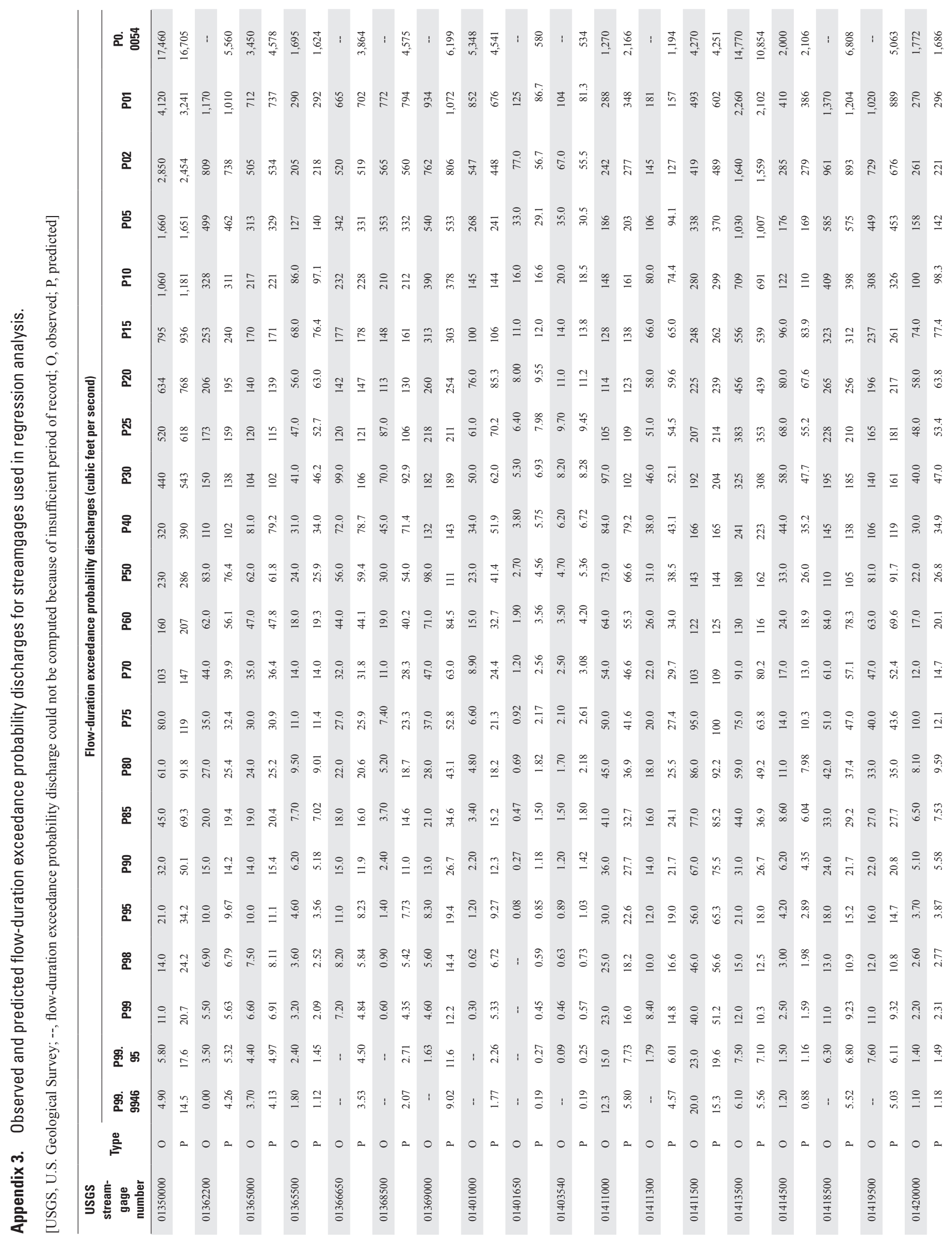




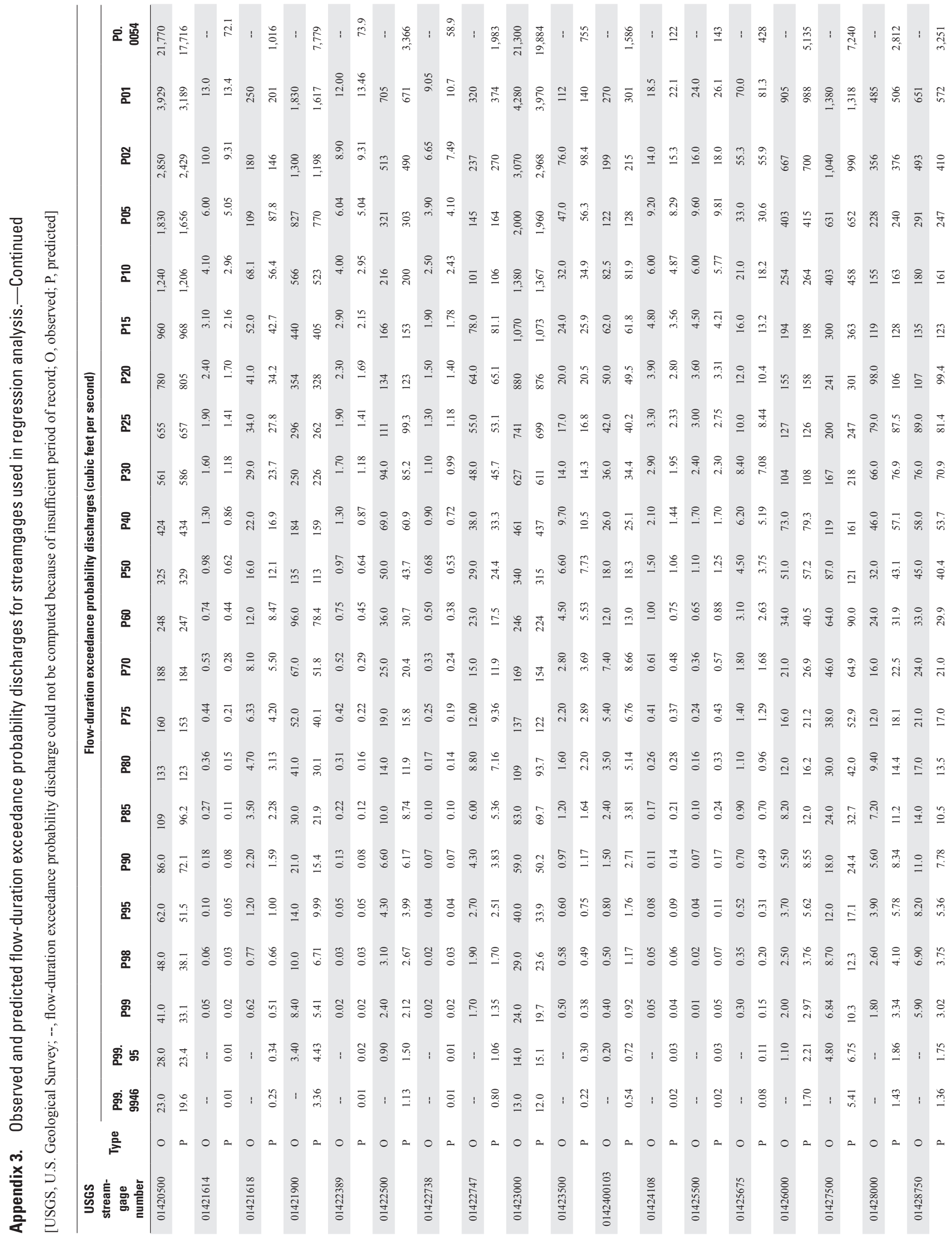




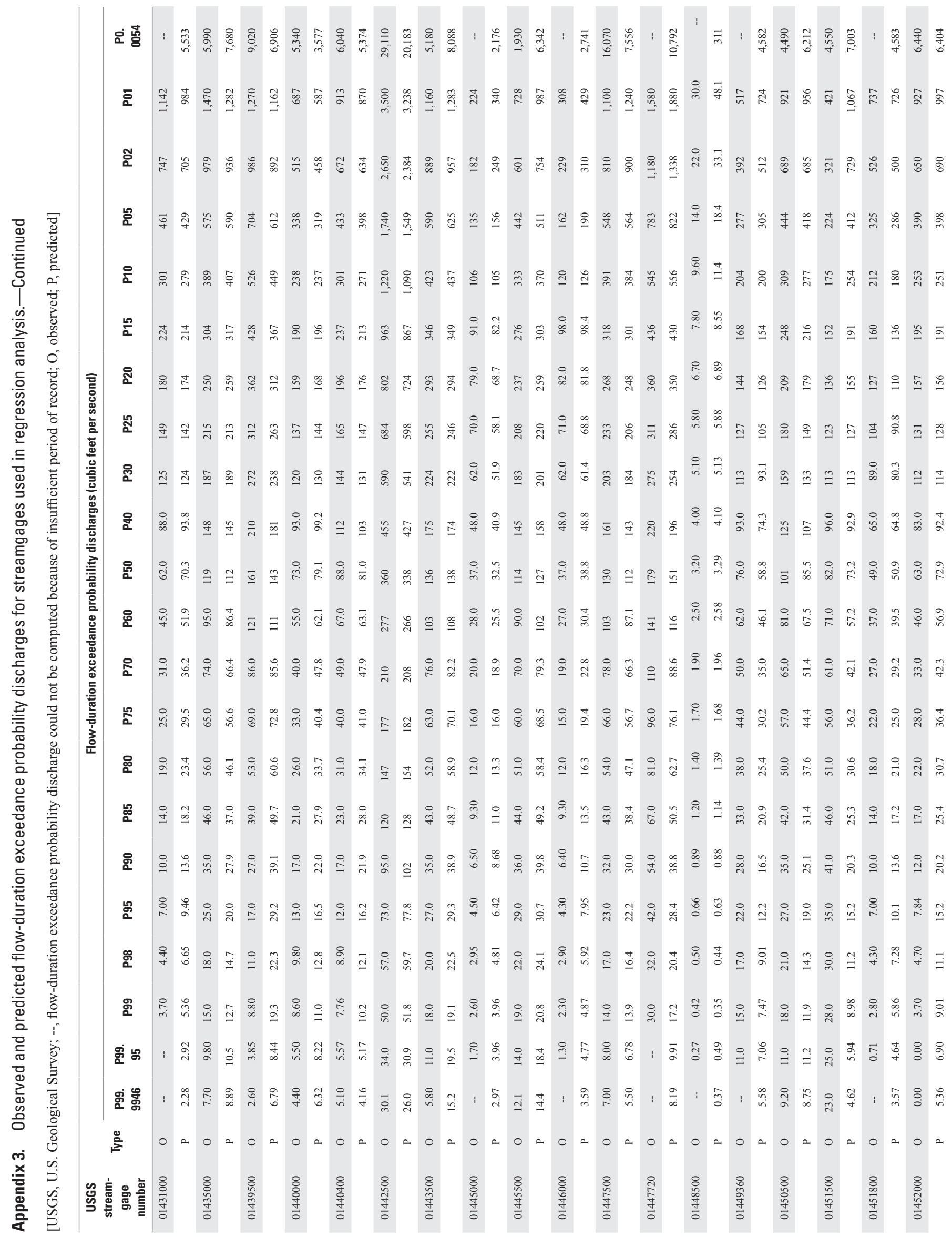




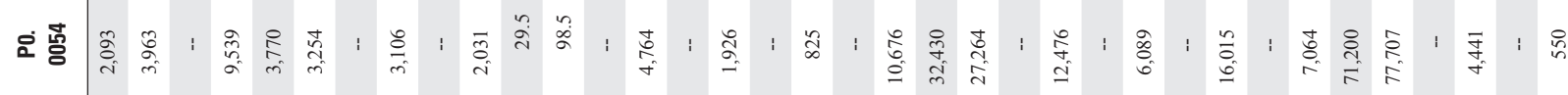
इ

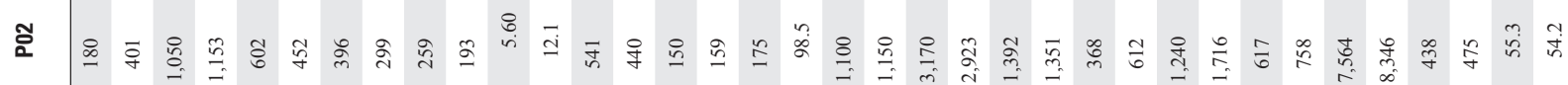

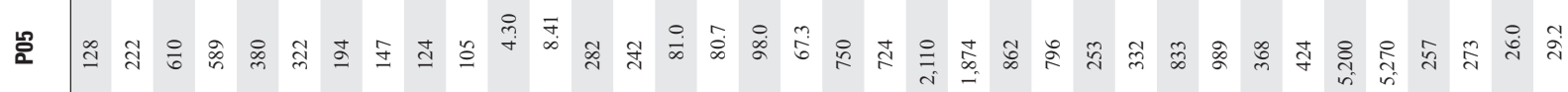

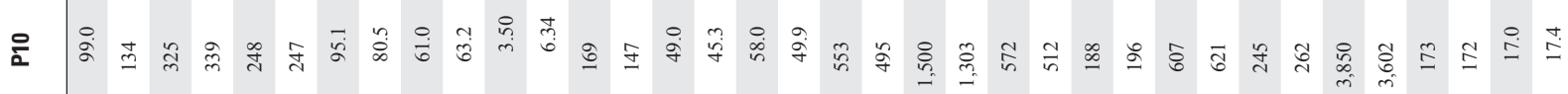

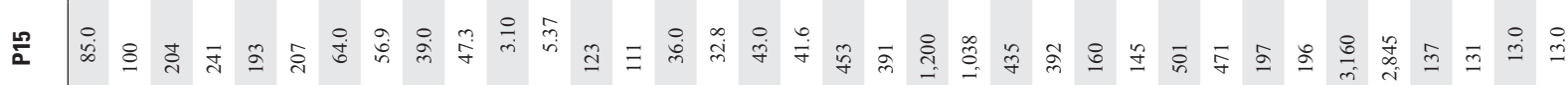

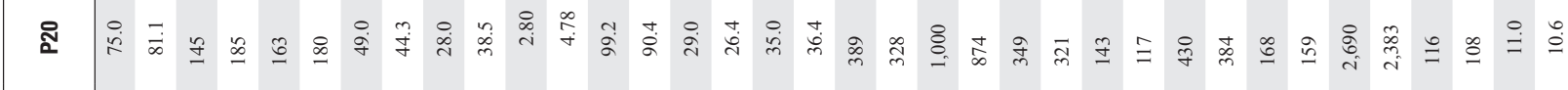
L \%

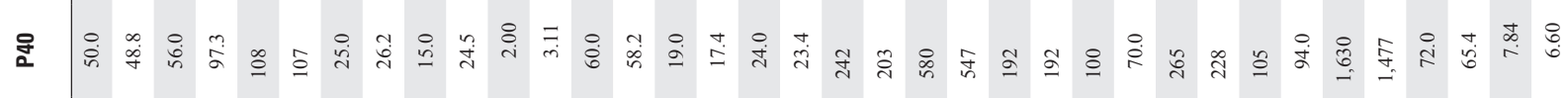

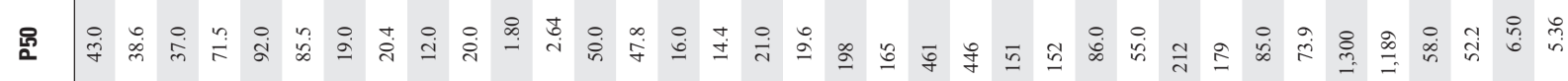

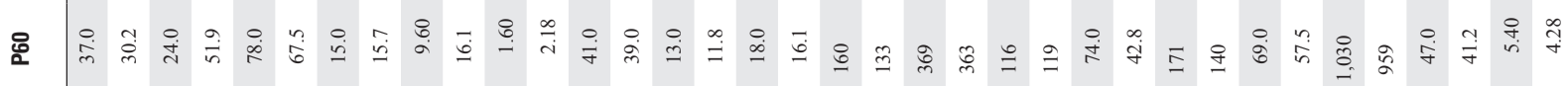

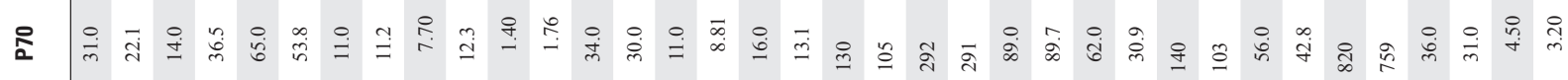

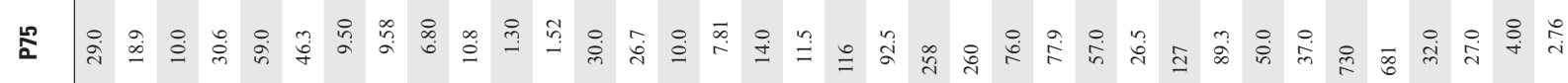

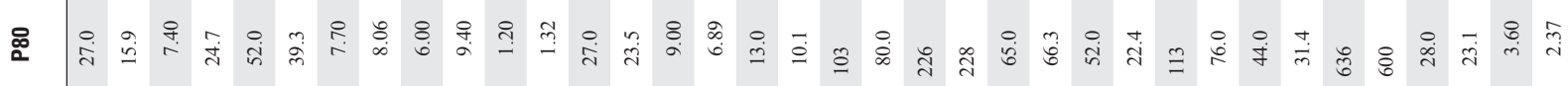

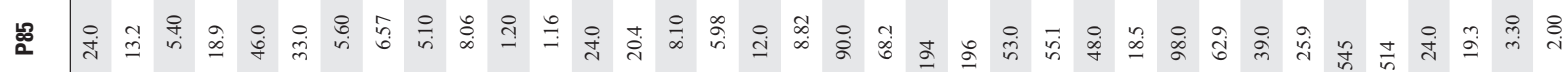

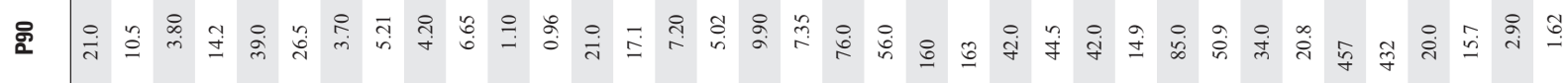

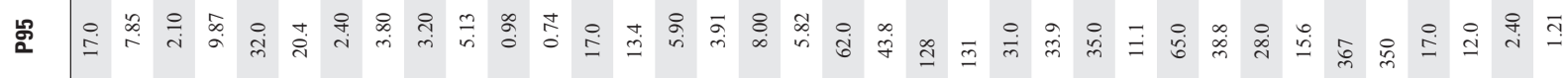

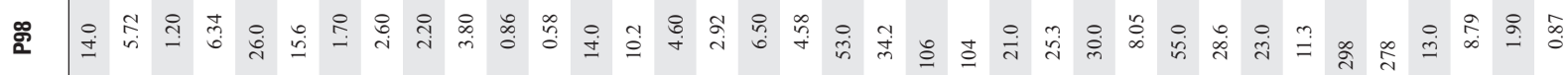

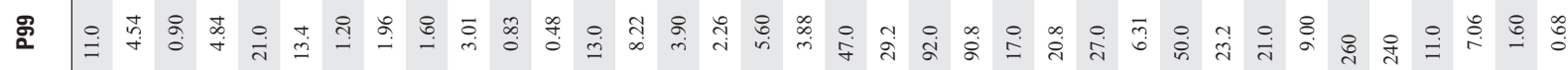

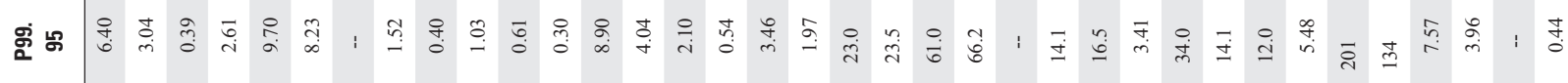

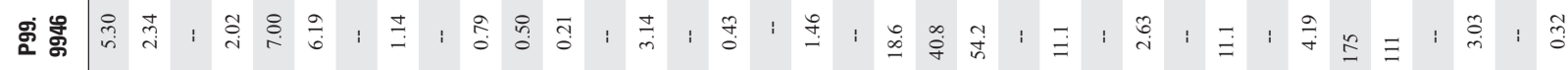

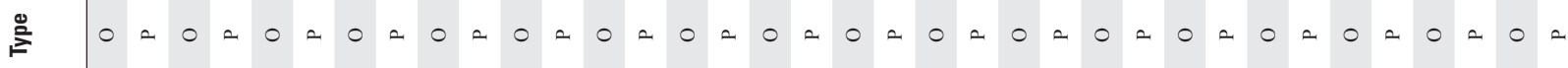

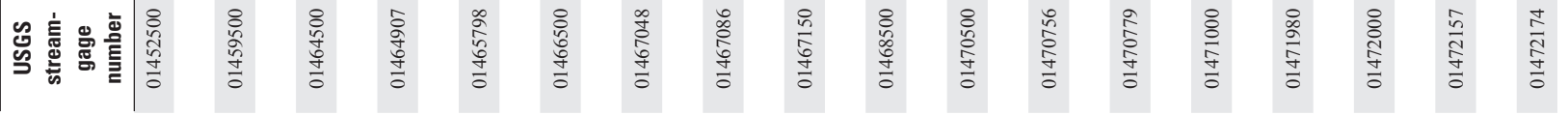




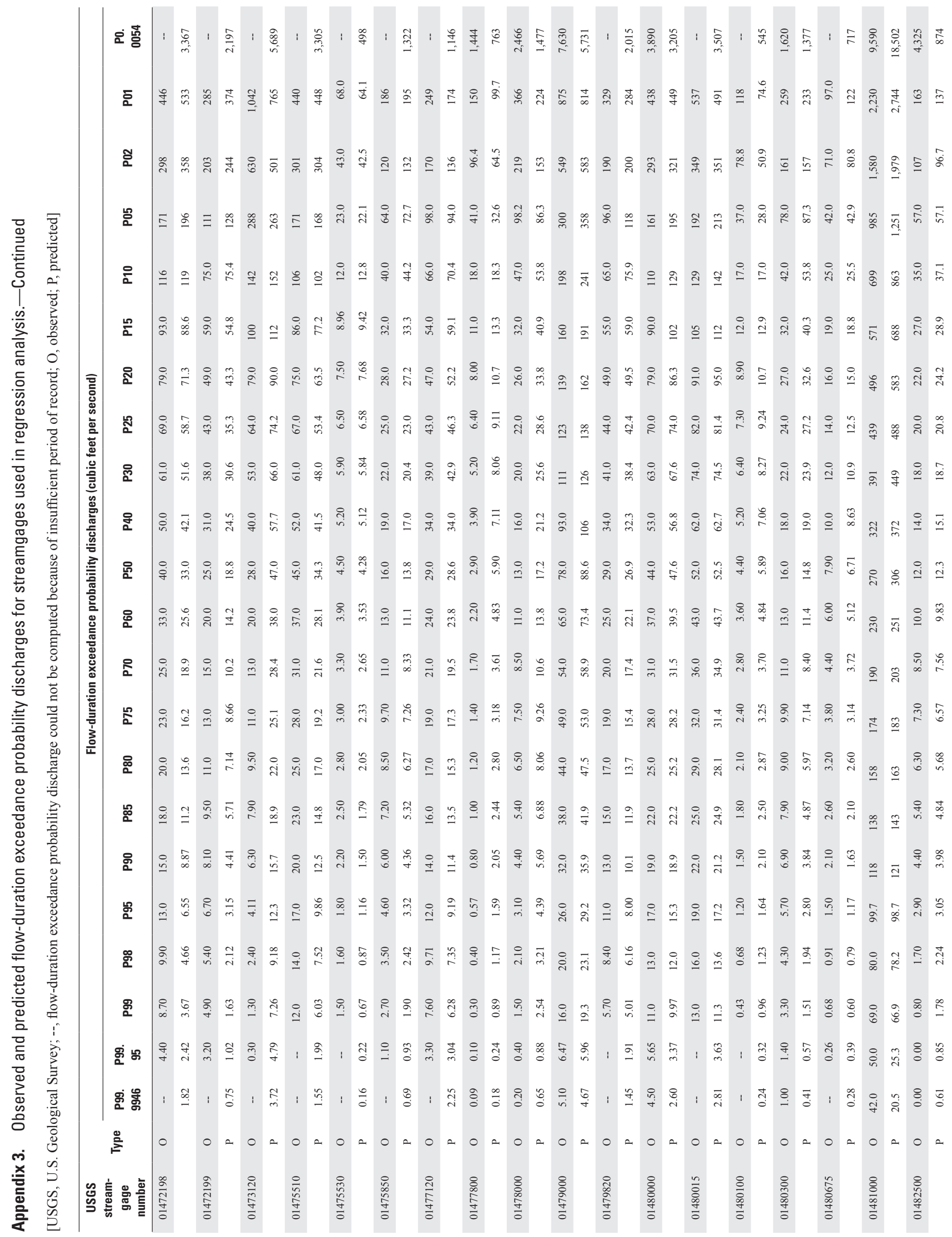




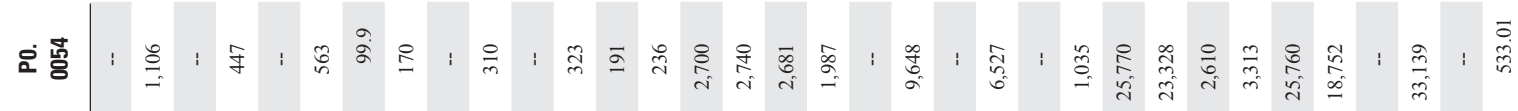

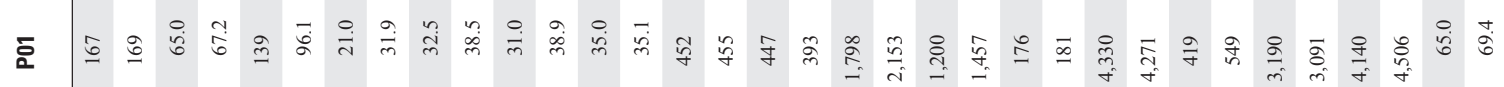
I $\Xi$ ป

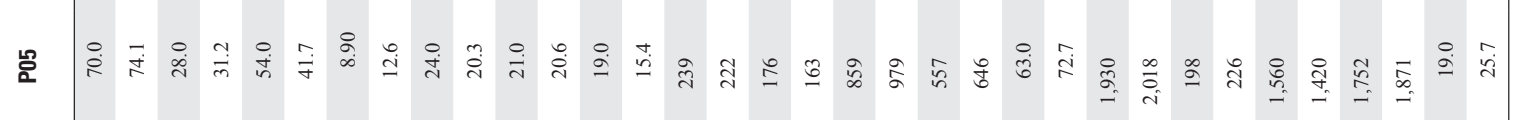

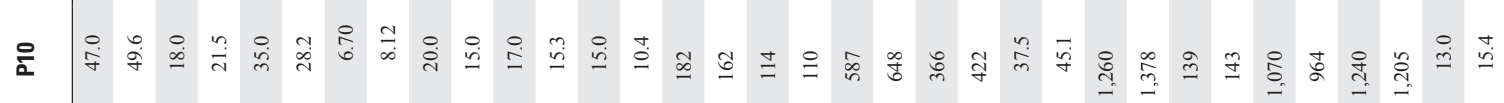

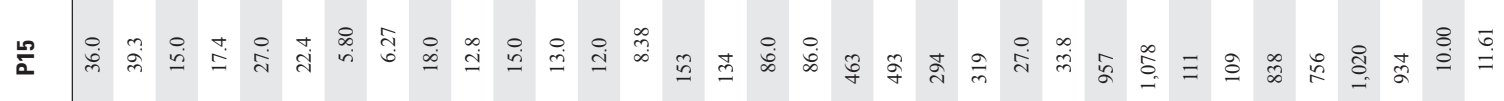

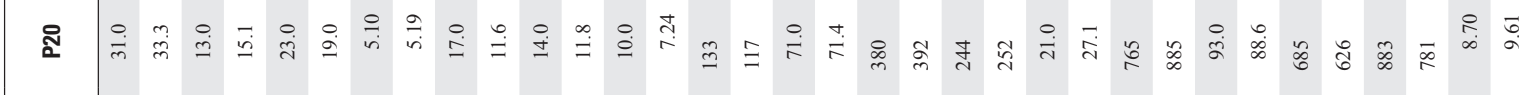

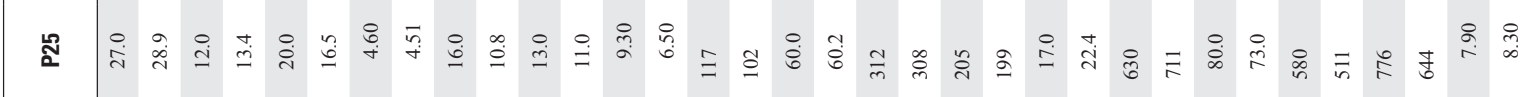
ס

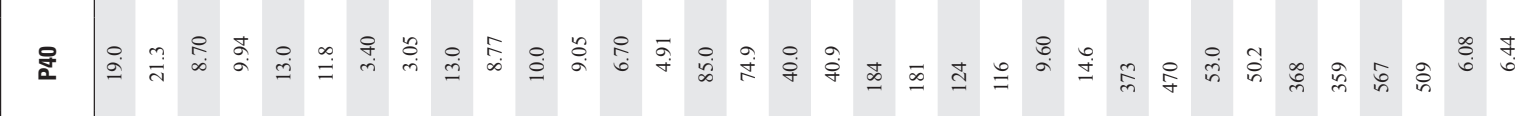

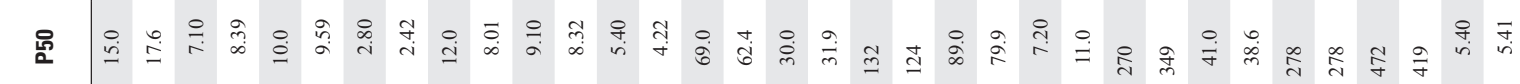
\&

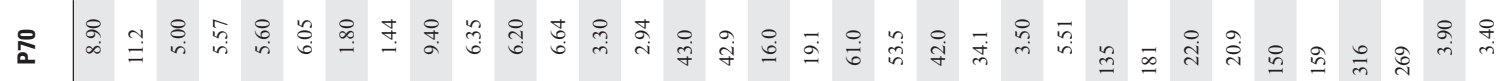

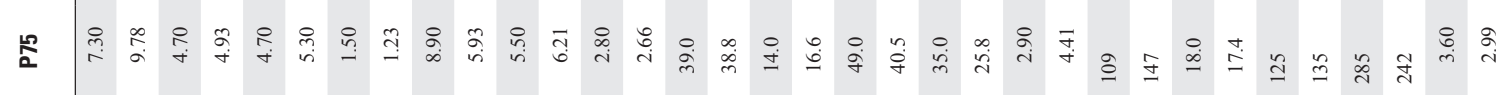

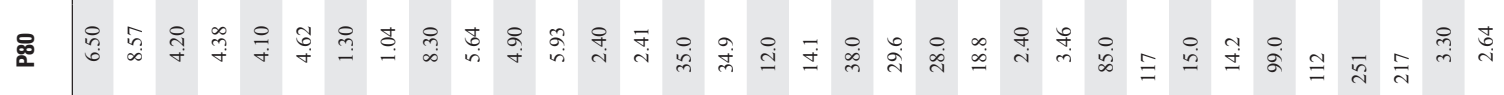

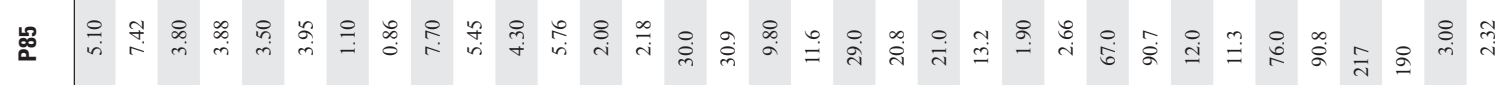

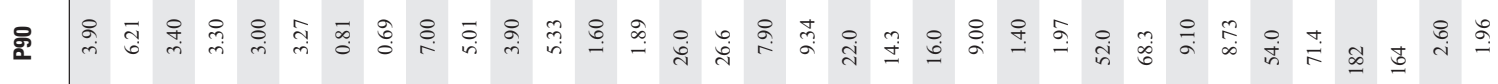

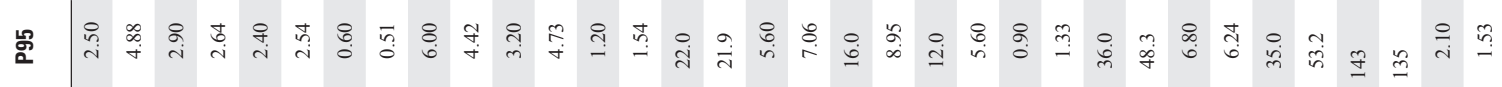

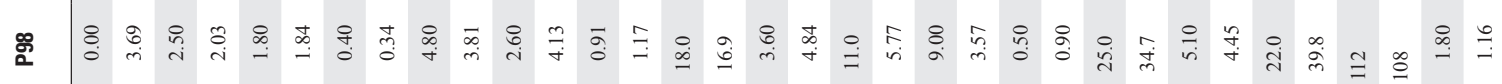

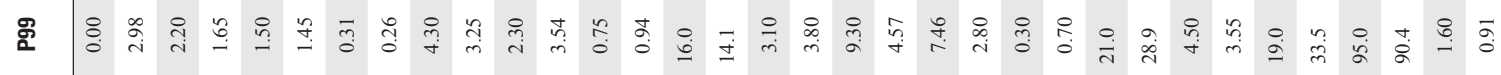

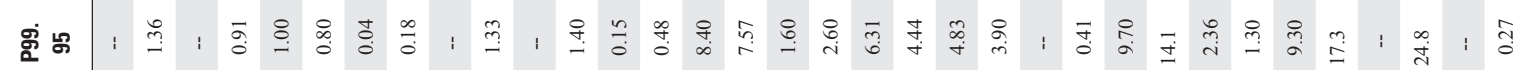

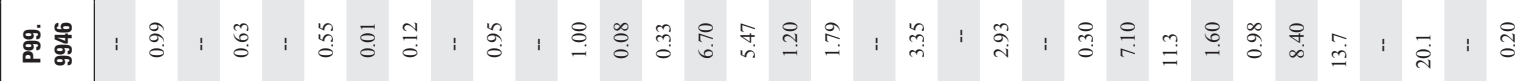

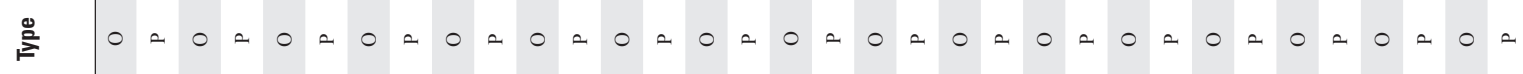

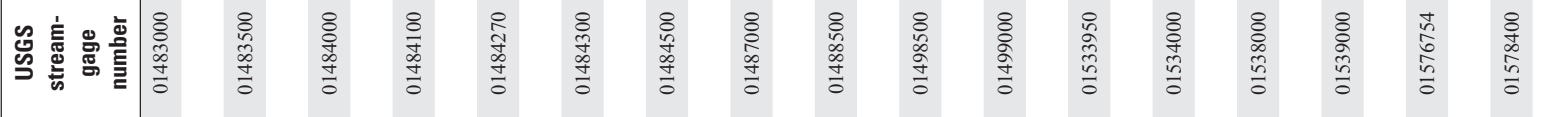


Prepared by USGS West Trenton Publishing Service Center.

For additional information, contact:

Sonya Jones

Coordinator-National Water Census

U.S. Geological Survey

1770 Corporate Drive, Suite 500

Norcross, GA 30093

or visit the National Water Census Web site at: http://water.usgs.gov/watercensus 
